University of South Florida

DIGITAL COMMONS

@ UNIVERSITY OF SOUTH FLORIDA
Digital Commons @ University of

South Florida

$7-2020$

\title{
An Assessment of Intercity Bus Services in Illinois
}

CUTR

Follow this and additional works at: https://digitalcommons.usf.edu/cutr_nctr

\section{Recommended Citation}

"An Assessment of Intercity Bus Services in Illinois," National Center for Transit Research (NCTR) Report No. CUTR-NCTR-RR-2020-05, Center for Urban Transportation Research, University of South Florida, 2020. DOI: https://doi.org/10.5038/CUTR-NCTR-RR-2020-05

Available at: https://scholarcommons.usf.edu/cutr_nctr/250/

This Technical Report is brought to you for free and open access by the National Center for Transit Research (NCTR) Archive (2000-2020) at Digital Commons @ University of South Florida. It has been accepted for inclusion in Research Reports by an authorized administrator of Digital Commons @ University of South Florida. For more information, please contact digitalcommons@usf.edu. 


\section{An Assessment of Intercity Bus Services in Illinois}

CUTR

Follow this and additional works at: https://scholarcommons.usf.edu/cutr_nctr

\section{Recommended Citation}

"An Assessment of Intercity Bus Services in Illinois," National Center for Transit Research (NCTR) Report No. CUTR-NCTR-RR-2020-05, Center for Urban Transportation Research, University of South Florida, 2020. DOI: https://doi.org/10.5038/CUTR-NCTR-RR-2020-05

Available at: https://scholarcommons.usf.edu/cutr_nctr/250/

This Technical Report is brought to you for free and open access by the National Center for Transit Research (NCTR) Archive (2000-2020) at Scholar Commons. It has been accepted for inclusion in Research Reports by an authorized administrator of Scholar Commons. For more information, please contact scholarcommons@usf.edu. 


\title{
Final Report CUTR-2020-05
}

\section{An Assessment of Intercity Bus Services in Illinois}

\author{
Prepared by \\ University of Illinois at Chicago \\ Metropolitan Transportation Initiative
}

Prepared For

National Center for Transit Research at the

Center for Urban Transportation Reserach

Paul Metaxatos, PhD

P.S. Sriraj, PhD

Emily Navarrete, Graduate Research Assistant

Michael Kenny, Graduate Research Assistant

July 2020

The contents of this report reflect the views of the authors, who are responsible for the facts and the accuracy of the information presented herein. This document is disseminated under the sponsorship of the U.S. Department of Transportation's University Transportation Centers Program, in the interest of information exchange. The U.S. Government assumes no liability for the contents or use thereof.

\section{CUTR. CUSF.EDU SOUTH FLORIDA}




\section{ACKNOWLEDGEMENT}

This study is based on research conducted under the sponsorship of the Metropolitan Transportation Support Initiative (METSI) from the Illinois Department of Transportation.

Additional support has been provided by Grant: DTRT12-G-UTC18 from the U.S. Department of Transportation.

The contents of this report reflect the view of the authors, who are responsible for the facts and the accuracy of the data presented herein. The contents do not necessarily reflect the official views or policies of the Illinois Department of Transportation, or the U.S. Department of Transportation. This report does not constitute a standard, specification, or regulation. 


\section{TECHNICAL REPORT DOCUMENTATION PAGE}

\begin{tabular}{|c|c|c|c|c|c|}
\hline $\begin{array}{l}\text { 1. Report No. } \\
79062-02-\mathrm{C}\end{array}$ & \multicolumn{2}{|c|}{ 2. Government Accession No. } & \multicolumn{3}{|c|}{ 3. Recipient's Catalog No. } \\
\hline \multicolumn{3}{|l|}{ 4. Title and Subtitle } & \multicolumn{3}{|c|}{$\begin{array}{l}\text { 5. Report Date } \\
\text { October } 2019\end{array}$} \\
\hline \multicolumn{3}{|c|}{ An Assessment of Intercity Bus Services in Illinois } & \multicolumn{3}{|c|}{ 6. Performing Organization Code } \\
\hline \multicolumn{3}{|c|}{$\begin{array}{l}\text { 7. Author(s) } \\
\text { Paul Metaxatos, PhD } \\
\text { P.S. Sriraj, PhD } \\
\text { Emily Navarrete, Graduate Research Assistant } \\
\text { Michael Kenny, Graduate Research Assistant }\end{array}$} & \multicolumn{3}{|c|}{ 8. Performing Organization Report No. } \\
\hline \multirow{2}{*}{\multicolumn{3}{|c|}{$\begin{array}{l}\text { 9. Performing Organization Name and Address } \\
\text { College of Urban Planning and Public Affairs } \\
\text { University of Illinois at Chicago } \\
412 \text { S. Peoria Street, Suite } 340 \\
\text { Chicago, IL } 60607\end{array}$}} & \multicolumn{3}{|c|}{ 10. Work Unit No. } \\
\hline & & & \multicolumn{3}{|c|}{$\begin{array}{l}\text { 11. Contract or Grant No. } \\
\text { DTRT13-G-UTC56; 79062-02-C }\end{array}$} \\
\hline \multirow{2}{*}{\multicolumn{3}{|c|}{$\begin{array}{l}\text { 12. Sponsoring Agency Name and Address } \\
\text { National Center for Transit Research (NCTR) } \\
\text { University of South Florida (USF) } \\
4202 \text { E. Fowler Ave., CUT100 } \\
\text { Tampa, FL 33620-5375 }\end{array}$}} & \multicolumn{3}{|c|}{$\begin{array}{l}\text { 13. Type of Report and Period Covered } \\
\text { Final Report } 9 / 1 / 2017-9 / 30 / 2019\end{array}$} \\
\hline & & & \multicolumn{3}{|c|}{ 14. Sponsoring Agency Code } \\
\hline \multicolumn{6}{|l|}{ 15. Supplementary Notes } \\
\hline \multicolumn{6}{|c|}{$\begin{array}{l}\text { Ongoing research about intercity bus operations in Illinois has reviewed federal and Illinois Department of Transportation (IDOT) } \\
\text { intercity bus policies and regulations and obtained experiences from other states regarding their strategies to meet federal and } \\
\text { state-level requirements. }\end{array}$} \\
\hline \multicolumn{6}{|c|}{$\begin{array}{l}\text { This study will examine the transportation providers' viewpoint about intercity bus services in Illinois. In this regard, the research } \\
\text { team will conduct a telephone survey of intercity bus service providers to assess how they meet the transportation needs of Illinois' } \\
\text { rural population. The outcome of this survey will give insight into the state of intercity bus practice, and provide information } \\
\text { about future such efforts in Illinois. }\end{array}$} \\
\hline \multicolumn{2}{|c|}{$\begin{array}{l}\text { 17. Key Words } \\
\text { Bus transit, Evaluation and assessment, Illinois, Intercity bus lines, } \\
\text { rural areas, surveys }\end{array}$} & \multicolumn{4}{|c|}{ 18. Distribution Statement } \\
\hline 19. Security Classif. (of this report) & \multicolumn{3}{|c|}{ 20. Security Classif. (of this page) } & $\begin{array}{l}\text { 21. No. of Pages } \\
46\end{array}$ & 22. Price \\
\hline
\end{tabular}

Form DOT F 1700.7 (8-72)

Reproduction of completed page authorized 


\section{TABLE OF CONTENTS}

SUMMARY

CHAPTER 1

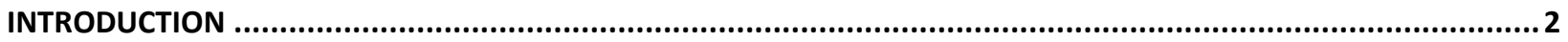

1.1 INTRODUCTION

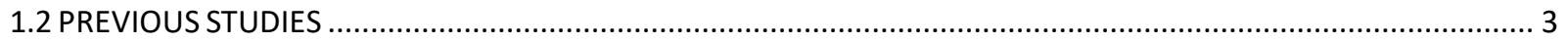

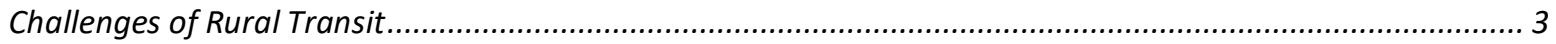

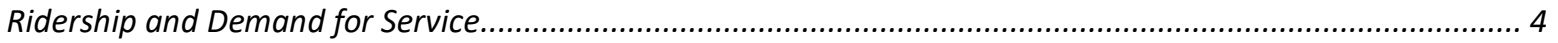

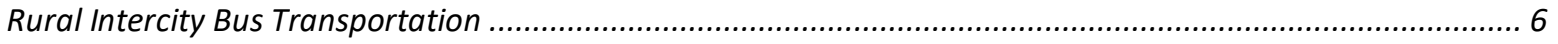

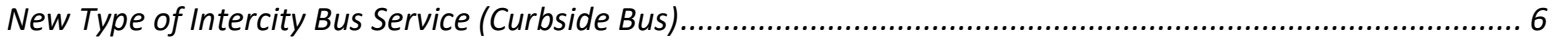

Competition between Curbside and Established Carriers ......................................................................... 8

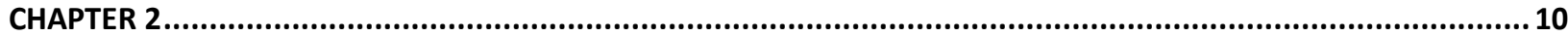

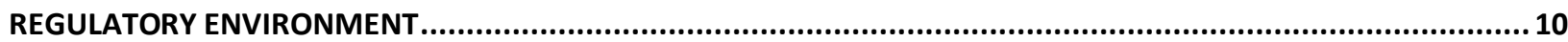

2.1 INTRODUCTION

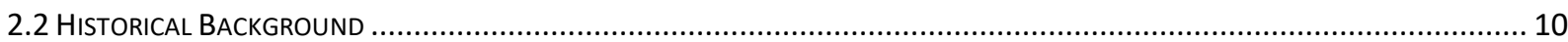

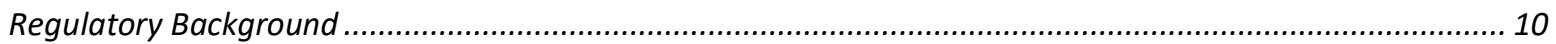

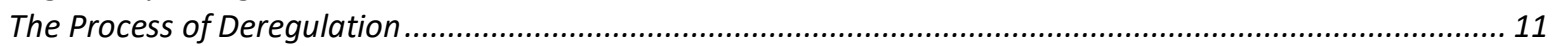

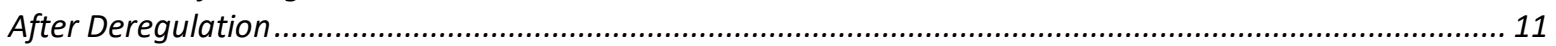

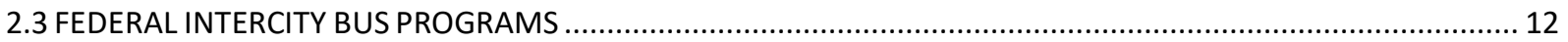

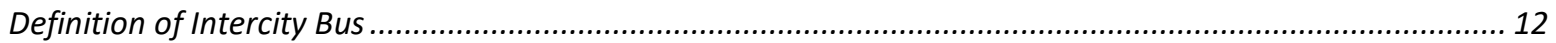

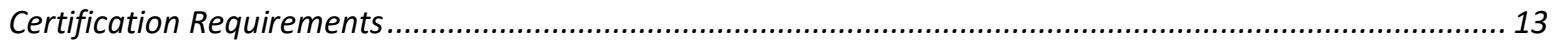

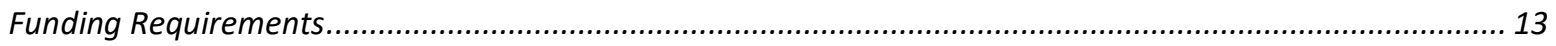

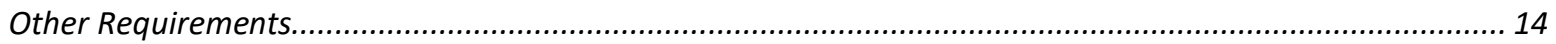

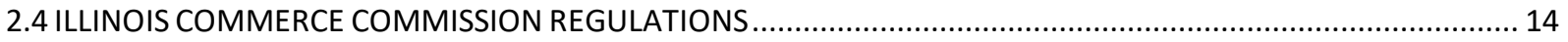

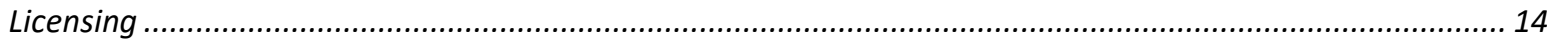

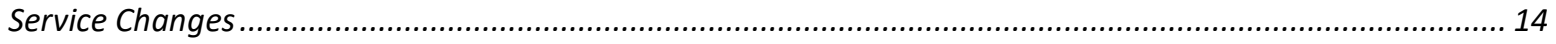

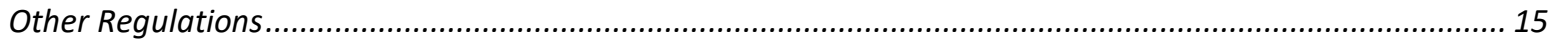

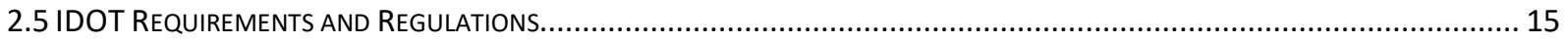

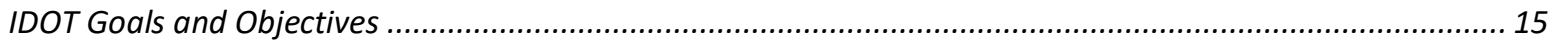

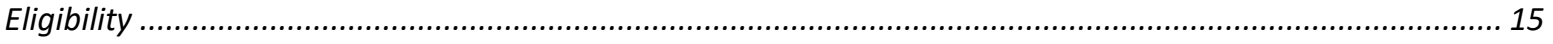

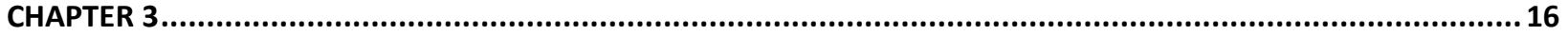

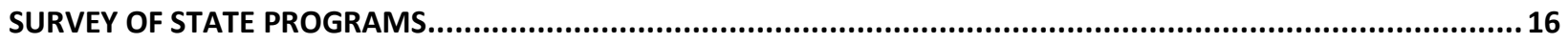

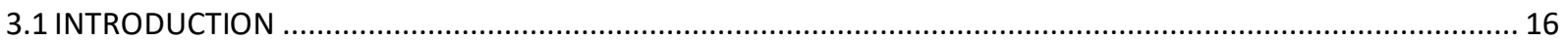

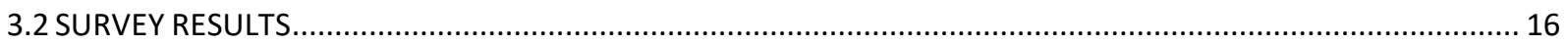

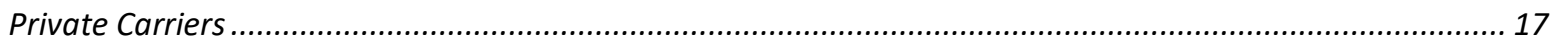

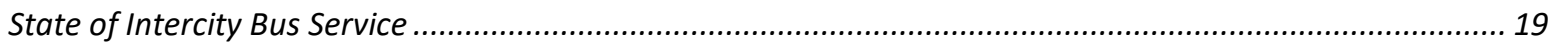

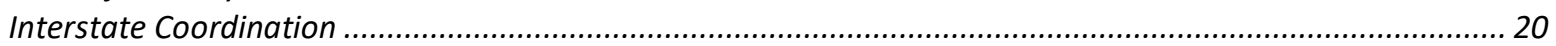

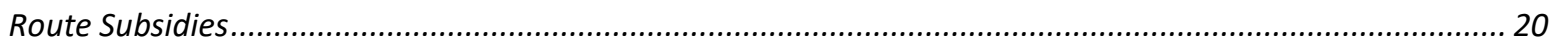

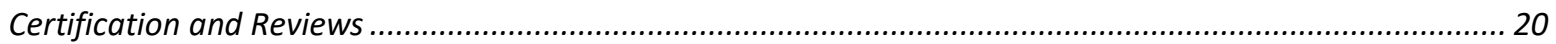

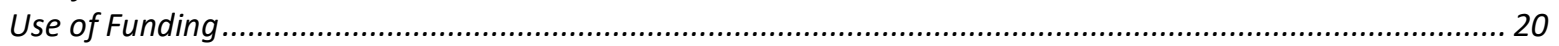

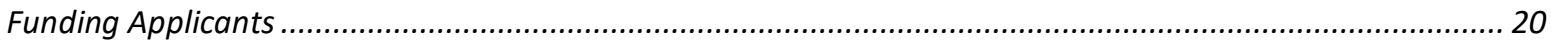

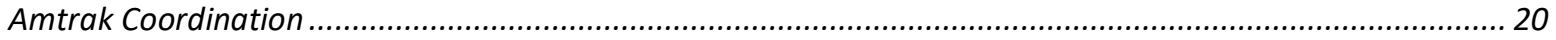

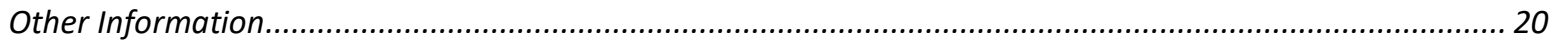

CHAPTER 4

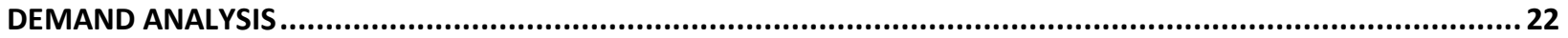




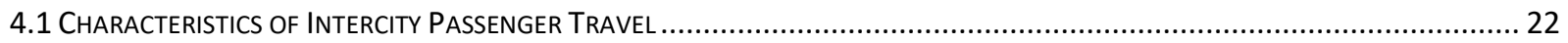

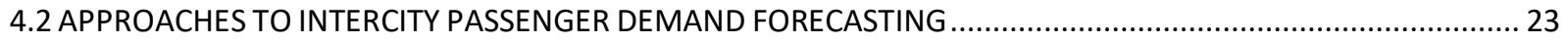

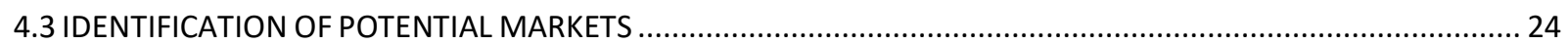

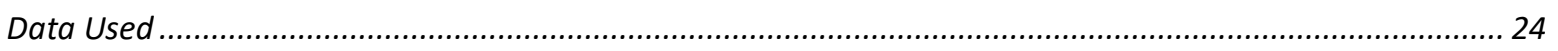

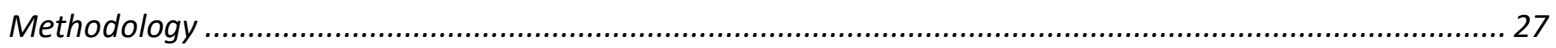

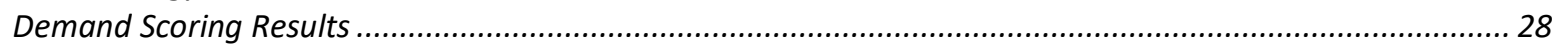

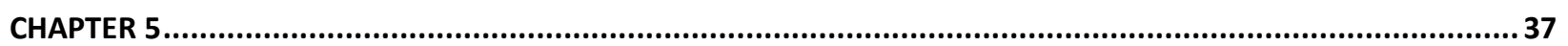

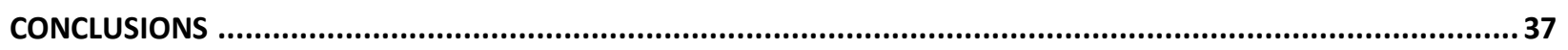

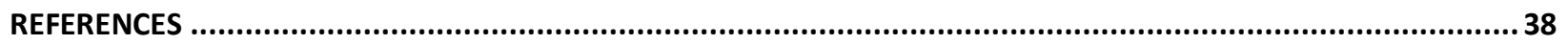

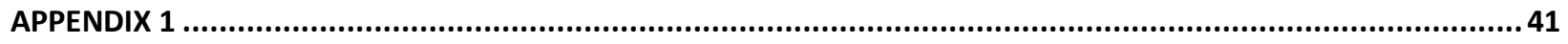

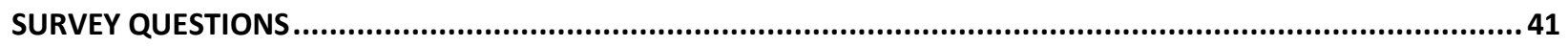




\section{SUMMARY}

Federal funding for intercity bus programs is available to states under Section $5311(\mathrm{f})$ of the Federal Transit Act. The act requires 15 percent of all federal funding for public transportation in non-urbanized areas be earmarked for intercity bus transportation, unless the state's governor certifies that the intercity bus service needs are adequately met. This report documents an assessment of intercity bus services in Illinois.

Upon reviewing federal and Illinois Department of Transportation (IDOT) intercity bus policies and regulations, the research team obtained experiences from other states regarding their strategies to meet federal and state-level requirements. Feedback from the states showed a variety of approaches to the funding requirements, even in Illinois' neighboring states. Some states focused exclusively on intercity bus; others considered the bus system's role in the statewide transportation network. Most states that subsidize service provide operating support; sometimes as a pilot project, sometimes not. Other states take a more capital focused approach.

A preliminary market analysis for Illinois identified several metropolitan areas with high interaction potential that could serve as origins or destinations of intercity bus services. Moreover, the analysis showed that there are a number of smaller cities with high interaction potential with their nearest metropolitan areas in regard to intercity bus services. 


\section{CHAPTER 1}

\section{INTRODUCTION}

\subsection{INTRODUCTION}

Until 1982, the intercity bus system operated under federal regulation that specified which cities would be served and what fares would be charged. Deregulation of intercity bus passenger transport in 1982 brought significant changes to the industry, affecting fares charged and places served. Yet, these changes did not spark the innovations and the efficiency improvements that occurred in airlines and rail freight (Schwieterman, 2016). The revival, however, of intercity bus service in the last decade, has renewed the interest of both transportation planners and policy makers.

The Intermodal Surface Transportation Efficiency Act (ISTEA) of 1991 under Section 5311(f) addressed the loss of service with a mandate that 15 percent of Federal funds for rural transportation be allocated to intercity bus service. The law requires that 15 percent of the total federal funding for public transportation in non-urban areas be earmarked for intercity bus transportation, unless the state's governor certifies that "the intercity bus service needs of the state are being met adequately."

Structured to encourage flexibility in state approaches, the program allows for a variety of approaches to meeting rural transportation needs, and allows diversion of the funds for other rural programs if the state's governor certifies that no need exists for intercity bus funds. States that wish to certify that the state's needs are being met and avoid the $15 \%$ set-aside requirement are generally expected to conduct a statewide assessment of available intercity bus service and unmet needs.

The Illinois Department of Transportation (IDOT) requirements for the Illinois intercity bus program follow from the federal requirements. IDOT's policy specifies three priorities: (a) maintaining, where possible, existing levels of Section 18 (rural bus) service "by funding any current Section 18 service that would qualify as intercity bus service"; (b) implementing an intercity bus program in compliance with current federal requirements; and (c) supporting Illinois intercity bus service to the greatest extent possible.

With these in mind, this report documents the activities undertaken to conduct a preliminary market analysis for intercity bus services in the State of Illinois. In this regard, the University of Illinois at Chicago (UIC) research team (a) reviewed the regulatory environment; (b) surveyed the experiences of other states; and (c) carried out an intercity bus demand analysis. In this regard, this report revisits the findings of a similar effort undertaken by an earlier UIC research team (Pagano et al., 2001). 
This introductory chapter will review previous studies followed by a discussion on regulatory environment in Chapter 2. A presentation of the findings from a survey of states is presented in Chapter 3. Chapter 4 presents results from the demand analysis followed by concluding remarks in Chapter 5.

\subsection{PREVIOUS STUDIES}

\section{Challenges of Rural Transit}

Hough and Mattson (2016) argue that low population densities and long travel distances are challenges transit agencies face serving people in rural areas. Public transit availability and use is significantly less in rural than in urban areas. Based on 2013 housing data, the research found that $73 \%$ of urban and $47 \%$ of suburban households have access to a grocery store by public transit compared to only $27 \%$ of households in non-metropolitan areas. Rural residents own more auto mobiles, drive significantly more miles because of long commutes and rely less on public transit to and from work. This dependence on automobiles creates difficulties for subpopulations such as older adults, people with disabilities and low income households. Rural areas are also known to have a higher percentage of older populations and people with disabilities than in urban areas making the need for alternative mobility even higher. Other findings include:

- Those who lack automobiles make almost $1 / 3$ fewer trips than those with vehicles.

- Disparity is greater compared to households with two or more vehicles.

- The need for rural mobility services for those who do not have access to vehicles creates a mobility gap.

Hough and Mattson also argue that although less efficient in low-density areas, transit in rural communities can be beneficial in three main ways:

- Transportation cost savings to the user - If transit is unavailable, other transportation methods may be more costly to use.

- More trips would take place with transit availability.

- Local economic revitalization - including not only the jobs created by the transit agency, but the jobs created in industries that supply inputs to public transit and the economic activity induced from the income generated by these new jobs.

With the demand growing for transit in rural areas, challenges such as maintaining and increasing staff at transit agencies is also growing. However, innovative and resourceful solutions have been successful to compensate for lack of funds. The type of transit provided in rural areas may differ from that in urban areas, but rural operators are showing that the service is equally important to users. 


\section{Ridership and Demand for Service}

Augustina et al. (2014) compare intercity bus markets between U.S. of which market is already established by deregulation in 1980s and Germany of which market is establishing by recent deregulation. Just after deregulation in U.S, the intercity bus market and ridership had been decreased due to continuously rising importance of cars and drastic increasing in aviation. However, as curbside intercity bus companies like Megabus started operations, the decreasing trend turned around and the ridership and the service have been expanding rapidly now. The authors describe reasons as "the rising congestion on highways, sharp increase in fuel prices, and more time-consuming check-in times at airports due to higher safety precaution" (p.248) as well as convenient, cheap, and frequent service of curbside intercity buses.

The authors built two regression models to explain the attributes influencing the fares and spatial features in U.S. intercity bus market. The data contains 2204 intercity bus routes by 68 different bus operators and this information is from Greyhound, Megabus, and other bus companies' websites including ticket price, distance, journey time, and number of stops.

The first regression model illustrates that the intercity bus ticket prices in the U.S. are increased when the distance of the service route is short, the number of stops is increased, and there are fewer competitors in the same service areas. In addition, this model also explains the difference of ticket prices between traditional intercity buses, Greyhound, and curbside intercity buses statistically. The second regression model shows impact of the spatial pattern in the U.S. intercity bus network on the service frequency. The result of the model describes that the average frequency per day in U.S. cities is significantly spatially influenced. This is because much more inhabitants concentrate on the East and the West coast in the U.S.

In another study, Mallett (2001) points that much less is known about intercity travel by lowincome households, even though many studies have been conducted for local transportation mobility problems among low-income household. The purpose of the author is to examine the long-distance (or intercity) travel behavior of low-income households in comparison with higher income households.

The data used in this report is 1995 American Travel Survey (ATS) conducted by the Bureau of the Census. The ATS contains information on the origin, destination, volume, and characteristics of intercity (long-distance) travel from approximately 80,000 households in the United States in 1995. After classifying the low-income households by its own definition, the paper compares the intercity travel information of low-income households by purpose, mode, travel distance, and travel stay through descriptive analysis and spatial indicators like neighborhood attributes.

People in low-income households who do not own a vehicle made one-third the number of trips made by the households with a vehicle. Passenger buses and rails are usually thought as most important mode for intercity travels of low-income people, but the result shows that these modes 
are still rarely used to travel long-distance. These people use air planes as twice as bus and train (9 percent air and 4 percent bus and train).

In another paper, O'Toole (2011) said that intercity buses are a 'directly competing mode' of transportation, which has resurged and been growing very fast. The author compares intercity trains and buses using information from bus companies' websites and the American Bus Association, as well as Amtrak operating information in the Boston-Washington corridor. He found that ridership of intercity buses has been grown almost twice as fast as ridership of Amtrak since 2006. Intercity buses carry at least 50 percent more passenger miles than Amtrak in the Northeast Corridor. In addition, intercity buses do not receive subsidies, while Amtrak accepts a lot of subsidies. Moreover, the fare of intercity buses are about a third of Amtrak's fare and only $10 \%$ of Amtrak's high speed Acela fares. Finally, intercity buses have almost $80 \%$ fewer fatalities per billion passenger miles than Amtrak and use 60\% less energy per passenger mile than Amtrak.

In another paper, Yang and Cherry (2012) examine the attributes of people who use intercity bus within Tennessee, particularly focusing on rural-urban connections and intercity bus routes. The authors look at emerging intercity bus travel patterns between rural and urban areas. Using data from an on-board survey in several intercity bus routes they profile typical intercity bus riders. In addition, the authors combine the National Household Travel Survey (NHTS) data with their on-board survey data and compare characteristics of intercity bus riders and trips using automobile.

The analysis shows that compared to automobile users, intercity bus riders are more likely to be of minority race, unemployed, unable to drive, and from low-income households. In addition, the authors found that an insufficient number of stops are located in high demand area. Overall, the authors argue that intercity bus stations in Tennessee are well-connected to destinations (i.e. $80 \%$ of bus stops connect to meaningful destination such as hospitals), but poorly connected to potential riders.

In another paper, Oster and Zorn (1986) examined the impacts of regulatory reform on intercity bus service in the United States. They argued that before the Bus Regulatory Reform Act of 1982 , the intercity bus was one of the very important transportation modes because bus service was "the most ubiquitous of the public modes" covering 14,600 communities in 1981 with strong support from low-income people, blacks, elders, and women uses bus service. The authors discuss the changes of the intercity bus industry, comparing before and after the Reform Act of 1982 observing the number of communities receiving scheduled bus service, and the total amount of scheduled bus service in each community in the sample twelve states: Arizona, California, Florida, Indiana, Massachusetts, Missouri, Montana, Oklahoma, Oregon, North Dakota, South Carolina, and South Dakota.

They observe that the number of communities with bus service had decreased steadily from 1975 to 1984 . Even though the decrease after the Act, 1982 to 1984 was steeper than before 
the Act, 1975 to 1982 , the decreasing trend was clear. The total bus service aggregated over all communities also had declined steadily from 1975 to 1984.

The authors observed that bus service terminations did not disproportionably focus on the communities with the most service dependent riders. In addition, intercity bus service companies initially cut their services excessively because of the deregulation freedom, but then restored back some of the service cuts similarly to the airline deregulation.

\section{Rural Intercity Bus Transportation}

Nutley (1996) focused on perceptions of transport-related problems and policy solutions in rural areas considering transportation resources, and the attitudes of decision makers in the United States and the United Kingdom. Using data from the 1990 U.S. Census and the 1991 U.K. Census, the author concluded that automobile-based paratransit systems would be the most feasible solution for transportation problems in rural areas, especially for the low-income and carless rural residents in USA.

Stommes and Brown (2002) evaluated change in all modes of rural transportation - highways, intercity passenger bus, intercity passenger rail, and air service as well as freight services in terms of various statistics and federal aid for transportation. The authors compared the 1980s and the 1990s in terms of government expenditure inf transportation and non-metro per capita federal aid under ISTEA by states, as well as the quality of rural public transit service using data from the Community Transportation Association of America.

The authors concluded that "transportation in rural areas is still in transition after a quarter century of deregulation (at the time), Federal devolution, and significant traffic increases across all modes" (p. 9). They argued that these changes have both positive and negative implications for transportation in rural areas. The transportation opportunities in some rural areas are improved by the airlines, a more efficient rail system, and increased charter bus tour. On the contrary, some rural areas experienced reduced transportation alternatives or opportunities such as reduced or no intercity passenger rail service, reduced rural bus stops and operating frequency of service, and decreased opportunities of air service.

\section{New Type of Intercity Bus Service (Curbside Bus)}

Klein (2009) discussed the emerging curbside intercity bus industry. The curbside intercity bus is a new type of intercity transportation which provides passenger service different from the traditional intercity bus such as Greyhound and Peter Pan. The curbside intercity bus stops on city streets like an intra-city bus instead of at bus terminals and charge low fares relative to traditional bus companies. Klein sees curbside buses having four characteristics: intercity service, low fares, primary reliance on curbside pickups, and regularly scheduled service. The purpose of the paper is to identify curbside bus operations and their characteristics, comparing 
them with primary competitors: traditional intercity buses such as Greyhound and Peter Pan, and intercity passenger rail, Amtrak.

The author compares the number of weekly total trips, costs, and travel time in three Northeast routes (NY-BOS, NY-PHL, and NY-DC) of curbside intercity buses, traditional intercity buses, and Amtrak. He collected frequency, fare, and travel time information from websites of the bus companies and Amtrak. He found that the average number of trips of curbside intercity buses was 437 compared to 161 and 144 for traditional intercity buses and Amtrak, respectively. Moreover, the fares of curbside intercity buses averaged $\$ 16.25$, but the fares of traditional intercity buses and Amtrak averaged $\$ 23.17$ and $\$ 69.33$ respectively. In addition, Amtrak was the fastest mode followed by curbside intercity buses and then traditional intercity buses in the same route. The difference of travel time between three modes was about 30 minutes. The author concludes that these modal differences have led to rapid ridership increases for curbside intercity buses. However, since there is not much regulation of the curbside intercity buses, the author also mentions concerns about safety issues.

In another paper, Klein (2015) discussed who is riding curbside intercity buses and how these new services are changing travel behavior. The author conducted an intercept survey and focus groups with intercity bus passengers in New York and Philadelphia to examine the demographic composition of the different sectors in the bus industry. Based on 770 valid survey responses and information from five focus groups, the author built an ordered logit model to compare the likelihood of using other modes compared to curbside buses.

The results showed that people boarding corporate curbside buses were more likely white and affluent and people boarding the Chinatown buses were more likely Asian, young, and male compared with passengers boarding other buses. There was also a significant relationship between using curbside buses and a decreased propensity to drive, as well as a relationship between using Amtrak and a curbside bus. After riding curbside buses, passengers were much less likely to use Amtrak for future trips. According to focus group participants, they were switching from Amtrak to curbside buses because of decreased travel costs and increased intercity accessibility.

In a recent report, Scott et al. (2013), found that the popularity of the curbside intercity bus services has been stimulated by competitive prices, convenient online ticketing, the rise in "transit lifestyles", and access to free, onboard Wi-Fi technology that caters to a younger demographic. The authors argue that the curbside intercity bus industry now represents the fastest growing mode of intercity travel in the United States outpacing air and rail transportation. Moreover, the authors report that the Commercial Motor Vehicle Safety Act of 2012 within the July 2012 two-year transportation reauthorization bill, Moving Ahead for Progress in the 21st Century set forth a strategic framework to improve the regulatory environment, provide a program of continuous improvement, and authorize greater rulemaking and enforcement authority of the Federal Motor Carrier Safety Administration (FMCSA). In addition, the authors report that state and local governments are addressing impacts of industry growth by initiating innovative approaches to manage curbside operations including permitting systems, idling laws, 
regulating curbside conditions, leasing or privatizing curb rights, and consolidating and/or centralizing bus operations in intermodal facilities. Finally, the authors conclude that policymakers, transportation officials, government leaders, safety oversight investigators and professionals, industry advocates, insurers, the private sector (e.g., developers of transitoriented development), and other stakeholders need to convene regularly to discuss key issues to keep this transportation mode safe, affordable, resilient, and competitive.

\section{Competition between Curbside and Established Carriers}

Schweiterman and Ames Fischer (2012) conducted a survey of passengers on discount curbside bus operators in Eastern and Midwestern U.S. cities. With 1,025 responses from six major cities in the East Coast and Midwest, this survey finds that curbside bus service should be regarded as a new mode. It generates a significant amount of new travel and attracts most of its passengers from commercial flights, trains and private automobiles.

This study conducted two surveys; one to curbside bus passengers and the other to conventional bus passengers. It was administered to six major cities in the East Coast and Midwest from November 2010 to June 2011 during weekdays. All cities in this study are considered major curbside bus hubs except for Indianapolis and St. Louis. Table 1.1 shows the distribution of survey responses.

Table 1.1. Distribution of Survey Responses

\begin{tabular}{|c|c|c|c|c|c|c|c|}
\hline Responses & $\begin{array}{c}\text { Chicago, } \\
\text { IL }\end{array}$ & $\begin{array}{c}\text { St. } \\
\text { Louis, }\end{array}$ & $\begin{array}{c}\text { Indianapolis, Philadelphia, } \\
\text { IN }\end{array}$ & $\begin{array}{c}\text { New } \\
\text { PA }\end{array}$ & York, NY & $\begin{array}{c}\text { Washington, } \\
\text { DC }\end{array}$ & Total \\
\hline $\begin{array}{c}\text { Curbside } \\
\text { Responses }\end{array}$ & 183 & 86 & 99 & 83 & 144 & 155 & $\mathbf{7 5 0}$ \\
\hline $\begin{array}{c}\text { Conventional } \\
\text { Responses }\end{array}$ & 173 & 32 & 70 & & & & \\
\hline & & & & & & & \\
\hline
\end{tabular}

The survey results show that $22 \%$ of curbside bus passengers would not have traveled if curbside bus was unavailable. These results are most likely due to discounted fares and express services offered. About $28 \%$ would drive or take a train. However, because of the larger traffic base in the East for Amtrak trains, the East Coast has a higher traffic diversion from trains than the Midwest. Table 1.2 shows the survey results of the percentage of all passenger modes of travel if curbside bus service was not available. 
Table 1.2. Passenger Mode of Travel if Curbside Bus Service Was Not Available

\begin{tabular}{|r|c|c|c|c|}
\hline Travel Mode & East (\%) & Midwest (\%) & Total (\%) & Greyhound (\%) \\
\hline Air & 6.1 & 15.2 & 10.6 & 20.3 \\
\hline Drive & 23.3 & 31.9 & 27.5 & 28.9 \\
\hline $\begin{array}{r}\text { Greyhound or other bus } \\
\text { line }\end{array}$ & 17.9 & 10.2 & 14.1 & NA \\
\hline Rail & 34.0 & 21.9 & 28.0 & 24.1 \\
\hline Other & 1.1 & 1.9 & 1.5 & 6.6 \\
\hline Would not have traveled & 22.0 & 21.9 & 22.0 & 20.1 \\
\hline
\end{tabular}

Curbside bus operators largely expanded their service from 2006 to 2011 . The majority of their clientele travel for personal business or pleasure, range from 18 to 35 years old and plan to use electronic devices en route. 


\section{CHAPTER 2}

\section{REGULATORY ENVIRONMENT}

\subsection{INTRODUCTION}

Intercity bus transportation has undergone several significant changes, both in Illinois and throughout the nation, in recent decades. Until 1982, the intercity bus system operated under federal regulation that specified which cities would be served and what fares would be charged. Deregulation of intercity bus passenger transportation in 1982 gave carriers greater flexibility in setting fares, routes, and service frequency. However, this caused many rural areas to lose service as carriers abandoned unprofitable routes. The decline in service continued with financial problems at Greyhound Lines, the nation's largest intercity bus operator.

The Intermodal Surface Transportation Efficiency Act (ISTEA) (Pub. L. 102-240) of 1991 addressed the loss of service with a mandate that 15 percent of federal funds for rural transportation be allocated to intercity bus service. This requirement allows for flexibility in how states address their intercity transportation needs, and allows diversion of the funds to other rural programs in states where no need exists for intercity bus funds. This program has provided new funding for intercity services, which has coincided with rapid growth in intercity bus ridership as new and innovative operators have entered the market (O'Toole, 2011). This growth in ridership is expected to continue, with gains of 29 percent in the top 200 markets by 2040 (Resource Systems Group, 2015). However, Illinois and many other states still require federal funding to subsidize operations and capital investments in rural areas that private carriers might otherwise underserve.

This section consists of three parts: a review of the historical background of the current intercity bus system; a summary of current applicable federal and state regulations and programs; and a review of recent research applicable to the process of determining intercity bus transportation needs.

\subsection{HISTORICAL BACKGROUND}

\section{Regulatory Background}

Intercity buses began as informal jitneys and taxis in the early 1900 s that steadily grew in size. These services became more regular and more formal, but by the interwar period concerns had grown about passenger safety and competition with the railroads (Klein, 2009). The Motor Carrier Act of 1935 sought to bring a greater degree of "order and stability" to the intercity bus industry. The Interstate Commerce Commission (ICC) was authorized to regulate the industry, with the intent of achieving affordable fares, adequate service levels, and predictable 
profitability. Under ICC regulation, service was widespread, but competition was severely restricted (Phillips, 1990).

In a changing interstate travel market that saw the airline industry deregulated in 1978 and Amtrak taking over the passenger rail system, intercity bus transportation remained regulated into the 1980s. As bus carriers saw their financial health deteriorate, pressure grew for deregulation of the bus industry, which proponents claimed would breathe new life into a constrained industry. Ultimately, pressure for deregulation led to the 1982 Bus Regulatory Reform Act (Phillips, 1990).

\section{The Process of Deregulation}

The academic community, in general, supported total deregulation of the intercity bus industry, as did most of the industry's players. Notable opponents included smaller firms, concerned that the absence of collective rate-setting policies would make it difficult for them to compete or offer coordinating service (Phillips, 1990).

The Act of 1982 and subsequent acts eased entry and exit of firms into intercity routes, requiring only that they comply with safety and insurance standards. The Act also gave regular route fare freedoms, which granted carriers some flexibility to set fares without ICC intervention. In its most significant change, the Act sharply reduced state control over interstate bus operators. Carriers could now eliminate unprofitable routes, and would no longer have to cross-subsidize between unprofitable and profitable routes (Phillips, 1990).

\section{After Deregulation}

Within a decade of the Bus Regulatory Reform Act, the industry had been dramatically transformed. The formerly strict rules for firm entry and exit had been eased to the point that the ICC required little more than proof of insurance coverage to grant a request to operate interstate service. At the state level, requirements had been similarly eased, resulting in a widespread loss of service to rural areas (Kahn, 1990).

The loss of protective regulation led to considerable financial upheaval among the industry's largest providers. Greyhound, the largest, merged with Trailways in 1987, despite the initial reluctance of the ICC to approve the merger. By 1990, Greyhound's operating revenues constituted more than 85 percent of the industry's total. Its patronage continued to shrink, however, and the firm entered Chapter 11 bankruptcy protection in 1990. Laidlaw, an international transportation provider headquartered in Canada, subsequently purchased the firm (Kahn, 1990).

Since 1998, the U.S. has experienced explosive growth in curbside bus services, which can offer extremely low fares because they do not use or pay for bus terminals and have low labor costs. The curbside industry began with small-scale services targeting primarily Chinese 
immigrants, but in 2006, Scottish-based Megabus entered as a serious rival to Greyhound. Greyhound and Peter Pan have since funded BoltBus, a competing curbside company on the East Coast. These services have only recently begun to be regulated by municipalities, who have imposed fines and restrictions to mitigate related pollution and congestion in their neighborhoods (Klein, 2009).

In recent years, as intercity bus travel has experienced a revival, operators have begun to invest in amenities - such as luxury services, power outlets, and $\mathrm{Wi}-\mathrm{Fi}$ - and improved web presence, including mobile apps, trip booking websites, and real-time bus trackers (Schwieterman, 2016).

\subsection{FEDERAL INTERCITY BUS PROGRAMS}

Federal funding for intercity bus programs is available to states under Section 5311(f). The law requires that 15 percent of the total federal funding for public transportation in non-urban areas be earmarked for intercity bus transportation, unless the state's governor certifies that "the intercity bus service needs of the state are being met adequately."

\section{Definition of Intercity Bus}

The Federal Transit Administration defines "intercity bus" as service that operates on fixed routes on a regular schedule making limited stops, available to the general public, connecting two or more urban areas not in close proximity, making "meaningful connections with scheduled intercity bus service to more distant points, if available." For purposes of the program, an urban area is broadly defined as "an area that includes a municipality or other built-up place that...is appropriate for a local mass transportation system to serve individuals in the locality."

Feeder service may be eligible for funding without these characteristics, if it connects to fixedroute trunk service. Feeder links to air or rail service may also qualify.

Excluded, ineligible forms of service include any air, water or rail service, commuter services oriented toward daily journey-to-work trips, and service that provides "extensive circulation within a region." No limit applies to vehicle size or the "identity of carrier," and package express services may be provided if such service is incidental to passenger transportation (Section 5311 Circular). The FTA's nine defining characteristics of intercity bus service are as follows:

- Regularly scheduled bus service

- Available to the general public

- Making limited stops

- Operating on fixed routes

- Connecting two or more urban areas not in close proximity

- Makes meaningful connections (if available)

- Predominantly passenger service (any package/goods service incidental)

- Not a commuter service 
- Not air water or rail service (bus only)

\section{Certification Requirements}

According to the FTA circular for Section 5311, states that wish to certify that needs are being met and avoid the 15 percent set-aside requirement are generally expected to conduct a statewide assessment of available intercity bus service and unmet needs. The legislative history indicates that the assessment of intercity bus needs may be made "relative to other rural needs in the state." The process emphasizes the need for obtaining public input from affected stakeholders, and specifies the involvement of "existing private intercity bus operators, before deciding to certify that the needs are adequately met rather than expending the required percentage of funds" (Section 5311 Circular).

If the state chooses to certify that needs are being met, that certification must be renewed annually for each fiscal year. A state may decide that an expenditure of less than $15 \%$ will be adequate to meet intercity bus needs, and may submit a "partial certification" to that effect. According to the agency, "FTA normally will not look behind a Governor's certification."

Program recipients are encouraged to consider the "intercity bus transportation needs of the entire state" and to coordinate their state's network with those of adjacent states to maximize connectivity and promote a usable interstate bus transportation network. Eligible programs include but are not limited to planning and marketing programs, capital facility programs, accessibility capital projects, operating grants, subsidies, demonstration projects, and coordination projects with rural transit operations. Ineligible programs include charter and tour operators.

\section{Funding Requirements}

The FTA requires states to involve private operators "to the maximum extent feasible." Funds may be dispersed to grantees through direct grants or through operating subsidies. The states may also disperse funds to local government agencies that, in turn, provide assistance to private sector service providers, or they may contract directly for services. States are encouraged to "use a merit based selection process to ensure that the private operator is qualified, will provide eligible service, can comply with federal and state requirements, and is the best, or only, provider available to offer service at a fair and reasonable cost."

On a net cost basis, FTA funds can cover up to $50 \%$ of operating costs and $80 \%$ percent of costs for capital projects and project administration. Capital costs in urban areas must be in support of service to non-urban areas. If the state fails to use its allocated funding, "the funds will lapse to the state". Further penalties in funding may apply if the state fails to fund intercity bus projects. 


\section{Other Requirements}

Complementary paratransit service is not required, although any service supported by Section 5311 grants should be accessible.

\subsection{ILLINOIS COMMERCE COMMISSION REGULATIONS}

The Illinois Commerce Commission (ICC) has minimal regulatory authority over intercity bus carriers. The Illinois Commercial Transportation Law (625 ILCS 5/18c Sub 6) specifically excludes regularly scheduled fixed-route services that do not serve an airport. The following services are also excluded:

- Services operated by schools and municipalities

- Services that charge per mile or per hour, such as taxis, charter operations, and contract buses

- Transportation in vehicles that carry eight or fewer people, including the driver

- Nonprofit ride-sharing

- Commuter vans, and fixed-route buses targeting commute trips

\section{Licensing}

All carriers subject to the Illinois Commercial Transportation Law must carry a valid license in order to operate. When licensing carriers, ICC considers whether the application was properly filed, whether a need for the proposed service exists, and whether the carrier is fit, willing, and able to provide compliant service. ICC also considers whether the proposed service is consistent with the public interest. In the case of carriers providing service to or from an airport, licenses are not issued unless public convenience and necessity require them.

\section{Service Changes}

Carriers may add or reduce service, or change service times, without prior authorization by notifying ICC. However, ICC has requirements for discontinuation of service. Carriers must submit an annual list (which may be updated monthly) of routes and points under consideration for discontinuation within the next year. After at least 30 days after submitting this list, the carrier may file a notice of intent to discontinue service. Between 60 and 90 days later, the carrier may formally propose discontinuance, which ICC must then approve or deny based on public need, revenue, variable costs, and the availability of reasonable alternatives. ICC may waive these notice requirements for good cause or prior compliance. 


\section{Other Regulations}

ICC has broad rate-making powers for transportation under its jurisdiction, and it enforces federal safety requirements, including hours of driver service. ICC also requires immediate reporting of accidents resulting in death, injury, or property damage.

\subsection{IDOT REQUIREMENTS AND REGULATIONS}

The Illinois Department of Transportation (IDOT) has an intercity bus implementation strategy that is consistent with FTA requirements. IDOT's State Management Plan lays out this strategy as part of a greater Section 5311 program. IDOT acknowledges the 15 percent set-aside requirement for intercity bus programs and prioritizes funding existing eligible grantees who provide intercity bus service.

\section{IDOT Goals and Objectives}

IDOT states three goals and objectives for its Section 5311(f) Intercity Bus Program:

1. Maintain current levels of Section 5311 services by funding existing eligible intercity bus service.

2. Implement an intercity bus program that is broad, flexible, and consistent with FTA requirements.

3. Support Illinois intercity bus service and participation of private operators as much as possible.

\section{Eligibility}

For operating assistance, projects are required to provide at least one of the following: additional intercity bus service to an existing Section 18 project that does not currently include defined intercity bus service; expansion of service on an existing intercity bus project; or new intercity bus service. Operating projects are also required to be compliant with both federal and Illinois Commerce Commission requirements, where applicable, and to fit the federal definition of intercity bus service.

Capital assistant projects may entail either rolling stock or for "a fixed asset with a unit or joint use allocated cost greater than $\$ 2000$," but must be used exclusively for intercity bus service. Capital projects are further required to be in compliance with FTA requirements and open to the general public. Capital projects in urbanized areas are eligible if intended to support service to rural areas.

Eligible technical assistance projects include planning and marketing projects for intercity bus service, and are required to be "necessary for the improvement of intercity bus service." 


\section{CHAPTER 3}

\section{SURVEY OF STATE PROGRAMS}

\subsection{INTRODUCTION}

The set-aside requirement for intercity bus funding under Section $5311(f)$ was designed to be flexible, allowing each state to determine the best way to improve its rural intercity bus network. A state may also elect to allocate the funds to other rural transportation needs if the existing intercity bus service adequately meets the state's needs.

A number of states have certified that their needs are being met, while others continue to implement programs to support intercity bus service. To learn more about how different states meet the requirements, the research team contacted a number of states that use available funds for intercity bus programs.

\subsection{SURVEY RESULTS}

UTC has received 10 responses to its state intercity bus survey from state DOT representatives. These states represent a variety of intercity bus situations and strategies. As seen in Figure 3.1, the 10 states represented are:

- Colorado

- lowa

- Michigan

- Minnesota

- Montana

- New Hampshire

- New York

- Ohio

- Oregon

- Vermont 


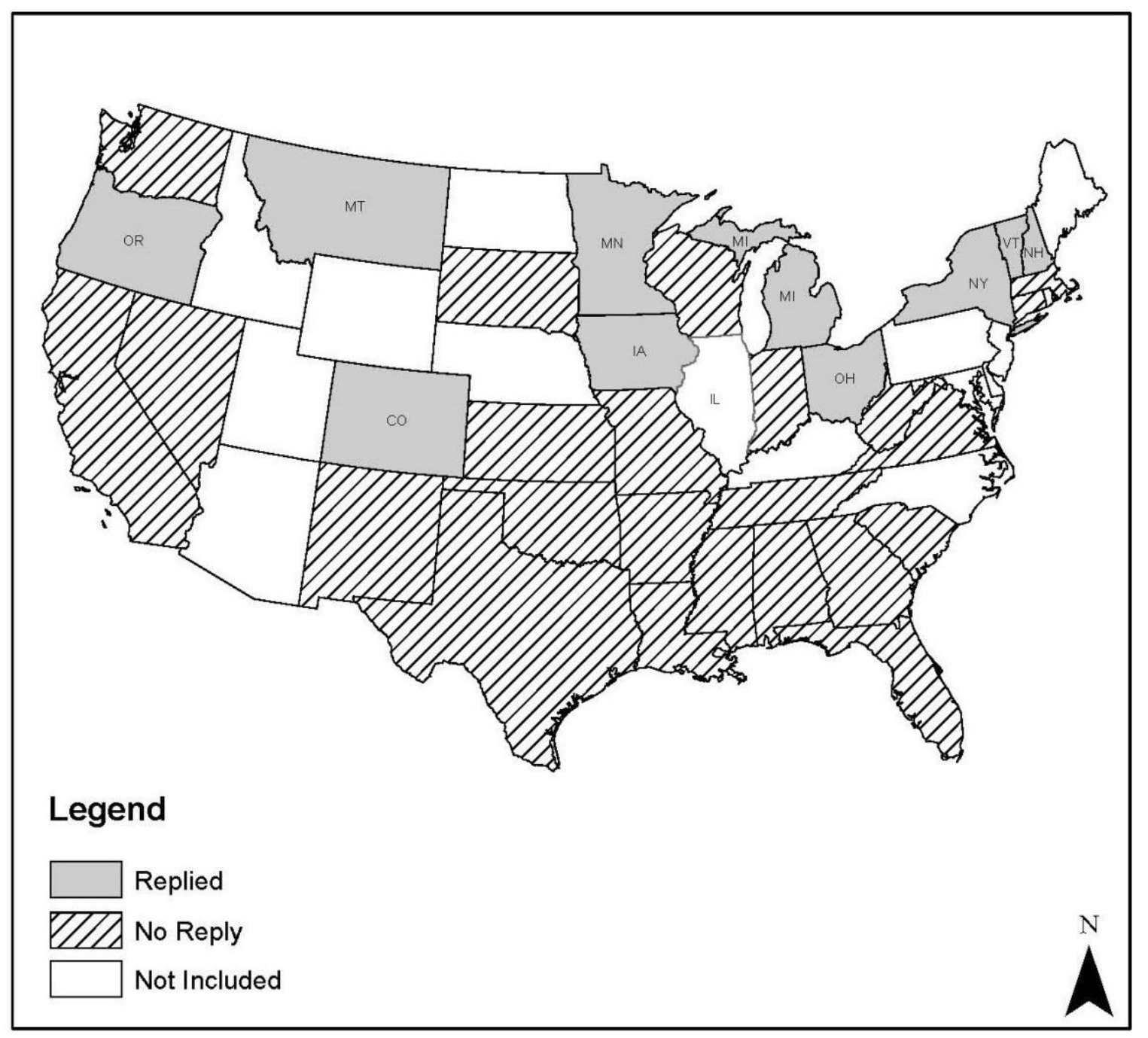

Figure 3.1 States participated in the survey.

The discussion below provides highlights from the survey.

\section{Private Carriers}

According to respondents, the following private carriers currently offer service in their states as shown in Table 3.1. 
Table 3.1 Intercity Bus Service Private Carriers

\begin{tabular}{|c|c|c|c|c|c|c|c|}
\hline State & Greyhound & Megabus & $\begin{array}{c}\text { Coach } \\
\text { USA }\end{array}$ & Trailways & BoltBus & $\begin{array}{c}\text { Jefferson } \\
\text { Lines }\end{array}$ & Other \\
\hline CO & $x$ & & & $x$ & & & $\begin{array}{c}\text { Black Hills } \\
\text { Stage Lines, } \\
\text { Los Paisanos, } \\
\text { Los Angeles - } \\
\text { El Paso } \\
\text { Limousine }\end{array}$ \\
\hline IA & & $x$ & & $x$ & & $x$ & \\
\hline MI & $x$ & $x$ & & & & & $\begin{array}{c}\text { Indian Trails, } \\
\text { Barons Bus, } \\
\text { Miller } \\
\text { Trailways }\end{array}$ \\
\hline MN & $x$ & $x$ & & & & $x$ & \\
\hline MT & $x$ & & & & & $x$ & $\begin{array}{c}\text { Salt Lake } \\
\text { Express, } \\
\text { Flathead } \\
\text { Transit, } \\
\text { Northern } \\
\text { Transit } \\
\text { Interlocal }\end{array}$ \\
\hline NH & $x$ & & & & & & $\begin{array}{c}\text { C\&J Bus } \\
\text { Lines, } \\
\text { Concord } \\
\text { Coach, } \\
\text { Dartmouth } \\
\text { Coach, Peter } \\
\text { Pan Bus Lines }\end{array}$ \\
\hline NY & $x$ & $x$ & $x$ & $x$ & $x$ & & $\begin{array}{c}\text { Birnie Bus } \\
\text { Tours and } \\
\text { First Transit, } \\
\text { Inc. }\end{array}$ \\
\hline $\mathrm{OH}$ & $x$ & $x$ & $x$ & & & & Barons Bus \\
\hline OR & $x$ & & & & $x$ & & $\begin{array}{c}\text { Valley } \\
\text { Retriever, } \\
\text { Central } \\
\text { Oregon } \\
\text { Breeze, } \\
\text { Pacific Crest } \\
\text { Buslines, } \\
\text { Oregon DOT } \\
\text { contract bus }\end{array}$ \\
\hline
\end{tabular}




\begin{tabular}{|c|c|c|c|c|c|c|c|}
\hline State & Greyhound & Megabus & $\begin{array}{c}\text { Coach } \\
\text { USA }\end{array}$ & Trailways & BoltBus & $\begin{array}{c}\text { Jefferson } \\
\text { Lines }\end{array}$ & Other \\
\hline & & & & & & & $\begin{array}{c}\text { service } \\
\text { provided by 3 } \\
\text { private } \\
\text { carriers }\end{array}$ \\
\hline VT & $\mathrm{x}$ & $\mathrm{x}$ & & & & & $\begin{array}{c}\text { VT Translines, } \\
\text { Adirondack } \\
\text { Trailways }\end{array}$ \\
\hline
\end{tabular}

\section{State of Intercity Bus Service}

We asked the states about how intercity bus service has changed in the last five years: the number of private rural intercity bus carriers, the amount of funding available, the number of private rural routes, and the number of rural scheduled intercity stops. In Table 3.2 below, an up arrow indicates the number increased over the last five years; a down arrow indicates a decrease; and a line indicates no change.

Table 3.2 State of Intercity Bus service

\begin{tabular}{|c|c|c|c|c|c|}
\hline State & $\begin{array}{l}\text { Number } \\
\text { of } \\
\text { carriers }\end{array}$ & $\begin{array}{l}\text { Available } \\
\text { funding }\end{array}$ & $\begin{array}{l}\text { Number } \\
\text { of rural } \\
\text { routes }\end{array}$ & $\begin{array}{l}\text { Number } \\
\text { of rural } \\
\text { stops }\end{array}$ & $\begin{array}{c}\text { Number } \\
\text { of } \\
\text { routes } \\
\text { per } \\
\text { week }\end{array}$ \\
\hline $\mathrm{CO}$ & - & - & - & - & 18 \\
\hline IA & $\downarrow$ & - & - & $\downarrow$ & Unsure \\
\hline MI & $\uparrow$ & - & - & $\downarrow$ & 5 \\
\hline MN & - & $\uparrow$ & - & - & 19 \\
\hline MT & $\uparrow$ & $\uparrow$ & $\uparrow$ & & 25 \\
\hline $\mathbf{N H}$ & - & $\uparrow$ & - & - & 6 \\
\hline NY & - & $\uparrow$ & - & - & 120 \\
\hline $\mathrm{OH}$ & $\uparrow$ & $\uparrow$ & $\uparrow$ & $\uparrow$ & 84 \\
\hline OR & - & $\uparrow$ & $\uparrow$ & $\uparrow$ & 13 \\
\hline VT & $\uparrow$ & $\uparrow$ & $\uparrow$ & $\uparrow$ & 4 \\
\hline
\end{tabular}




\section{Interstate Coordination}

All 10 respondents indicated that their states have services across state lines, but only 4 out of 10 indicated that they coordinate with the other state(s) in any way.

\section{Route Subsidies}

Five of the 10 respondents said that more than half of their intercity buses' mileage is unsubsidized, while only two said that less than 10 percent of their mileage is unsubsidized.

\section{Certification and Reviews}

None of the 10 states in the survey indicated that they had submitted a certification that their intercity transportation needs were being met. However, 8 of the 10 states said that their intercity bus support programs were evaluated during the most recent FTA triennial reviews.

\section{Use of Funding}

All 10 respondents said that their states use Section 5311(f) funding to subsidize operations, and 7 out of 10 said that they emphasize operations subsidies (the other three emphasize operations, capital, and marketing/support equally). Two states, New Hampshire and Colorado, indicated that they spend funds only on operations subsidies.

\section{Funding Applicants}

Nine out of 10 respondents stated that private, for-profit carriers are the ones that most often apply for and receive 5311(f) funding (Oregon was the exception, with private, non-profit carriers).

\section{Amtrak Coordination}

Only three states (Colorado, Michigan, and Oregon) have combined ticketing between Amtrak and their intercity bus services. However, six states have Amtrak branded buses to make connections to rail.

\section{Other Information}

We have also received qualitative information from the respondents on their 5311 (f) grant application processes, whether they have experienced problems spending the 15 percent setaside, and whether they could be spending it better.

Summary 
In summary, the majority of the states surveyed subsidize intercity bus service using 5311 (f) funding. Intercity bus carriers primarily serve large urban areas. However, they have found it difficult to sustain their operations in rural areas. In this respect, feeder services play a vital role in bridging the gap between rural communities and the proximate urban areas that are catered by Intercity bus carriers. Communities over 2,500 population could have feeder services that connect with intercity bus services in the nearest urban area. Feeder services, although not covered in this report, can be used as a means to connect to a city where there is a bus/rail station or airport. Unlike intercity bus service, which is a fixed route provider, feeder service can be categorized as demand-responsive. This service provides curb-to-curb service from their home to a final destination. Per the FTA regulations, feeder services are eligible to receive 5311(f) funding as long as they meet the requirement of connecting to an intercity bus service. A taxi service is also an example of such a service. In Illinois, as shown in Chapter 4 of this report, feeder services to intercity bus service at the closest MSA city would have the greatest chance of being financially viable. The higher the potential for interaction between nonMSA urban places and nearest MSA city, the better are the mobility options for the local population and in turn an expanded catchment area of demand for intercity bus services. The demand profile for these services is accordingly explored in the next chapter. 


\section{CHAPTER 4}

\section{DEMAND ANALYSIS}

\subsection{CHARACTERISTICS OF INTERCITY PASSENGER TRAVEL}

Intercity passenger travel includes a variety of trip purposes such as work trips, business-related and non-business travel. Work trips constitute a small proportion of intercity passenger travel. These include trips from the place of residence to the place of employment (i.e., a manufacturing plant, a retail store or shopping mall, or a public or private institution, such as a hospital or a university) that cross municipal boundaries and do not include trips within an urbanized area. Business-related travel may involve product sales and service delivery, obtaining training, travel to business meetings and conferences, travel to company's head offices and trips associated with government business. Non-business trips include trips made for shopping, recreation (e.g., vacationing, attending sports events, concerts, etc.) and personal travel that is not job-related (e.g., visiting friends and relatives, school attendance, trips to doctors, lawyers or other special services not found locally, etc.).

These types of trips exhibit different elasticity characteristics regarding the choice of mode. Work trips are usually cost inelastic, and travel time elastic. Business trips are time sensitive, as well as sensitive to schedule frequency and reliability of service, but, probably, cost inelastic. On the other hand, recreation trips are cost sensitive and less time and convenience elastic than work and business-related trips. Moreover, personal travel is, in general, more cost elastic than recreation travel.

On a different note, shopping trips are made more often than recreation trips and for shorter distances than both recreation and personal travel. Moreover, long-haul business travel exhibits variability on an annual basis and non-business travel on a seasonal basis.

Long-haul travel is not very sensitive to transportation attributes such as schedule frequency and modal access and egress times because the travel time is usually large enough that the variations brought about by changes in these attributes are not very critical. On the other hand, short-haul travel often involves a priority choice of mode and a choice of route. In addition, the travel time is usually sufficiently small so that frequency and access characteristics become important attributes. Furthermore, short-haul trips are made with greater frequency than are long-haul trips and exhibit weekly, and sometimes daily variation.

The literature suggests that the captive ridership of intercity bus service is very small and is not dominated by the rural poor or the rural elderly (Sperling and Goralka, 1988). Further, the market for intercity buses is largely circumstantial depending mostly on convenience, comfort and competitive fares. Potential patrons may include those living near a bus stop or with a destination near a bus route and who do not place a high value on time. 


\subsection{APPROACHES TO INTERCITY PASSENGER DEMAND FORECASTING}

In the context of intercity passenger forecasting, corridor, statewide, regional and national models have been used. The prevalent theory, expressed in the early 1960s (Burch, 1961) is that the characteristics of intercity travel are inherently different from those related to intra-urban travel. In other words, it is assumed that people travel according to a somewhat different set of rules over longer distances and between metropolitan areas.

Intercity models can essentially be divided into four types on the basis of data and structure (USDOT/FHWA, 1999): aggregate direct-demand models, aggregate sequential models, disaggregate direct-demand models and disaggregate sequential models. Intercity travel demand models can be further classified as mode-specific or multiple-mode and trip-purposespecific.

Aggregate models make use of the socioeconomic information for origin-destination pairs and can also include the service characteristics of the modes of travel. Dissagregate models go further to examine the motives and characteristics of the trip makers at the personal or household level.

Direct demand (econometric) models compute the desired travel information in one step. Sequential models, on the other hand, divide the modeling process into several steps. The earliest intercity models were of the direct demand type and were developed in the 1960s (Koppelman et al, 1984). By the late 1970s direct-demand models included an increasingly wider range of variables to account for the enormous variety of factors that influence travel behavior.

In the early 1980s, the emphasis shifted from aggregate to disaggregate sequential (Koppelman et al, 1984) and direct-demand modeling (Moavenzadeh, 1983). Modeling of intercity bus travel has proved to be difficult (Dean, 1982). Oberhausen and Koppelman (1982) review time-series analysis of air travel. Finally, Gilbert (1974) addressed the recreational trip purpose in a disaggregate model.

In spite of the research involving the characteristics of intercity travel and its concentrations on econometric models and probability-based models, passenger travel forecasting, as practiced by the various state DOTs, has remained much more basic. Recent accounts about the state of the practice (USDOT/FHWA, 1999) report that most of the states do not do travel modeling on a statewide level. The majority of the DOT's do forecasting for specific projects only, and forecasts are made based on historic trends.

For the states that are engaged in some type of modeling process, the models used are all 'four-step' models in the urban transportation planning system (UTPS) tradition. The practice became so popular that in 1973, the FHWA perceived the need to standardize the thinking about statewide modeling and issued a guidebook on the subject, effectively institutionalizing the UTPS-style model for statewide use (USDOT/FHWA, 1973). The enthusiasm for developing 
statewide models waned in the 1980s due to funding cuts and frustration with the results. By the early 1990s, prompted by new federal legislation (CTAA and ISTEA), several states were rethinking their strategies.

More recent efforts include the development of sketch planning tools to forecast demand for rural intercity bus services (Fravel et al, 2011), and the historical review by Ashiabor et al. (2007), and statewide travel forecasting models (Horowitz, 2006).

\subsection{IDENTIFICATION OF POTENTIAL MARKETS}

\section{Data Used}

First, the universe of places in Illinois with populations over 2,500 (2000 Census) was identified, then divided it into two parts: (a) Metropolitan Statistical Areas (MSAs), as defined in the "Standards for defining Metropolitan and Micropolitan Statistical Areas" (Federal Register, Vol. 65 , No. 249 , December 27,2000 ), that is, "an area containing a recognized population nucleus, including at least one city with 50,000 or more inhabitants, and adjacent communities that have a high degree of integration with that nucleus"; and (b) Non-Metropolitan Statistical Areas (non$M S A s$ ), that is, any urban place inside Illinois that has population above 2,500 , and it is not part of an MSA. The Bureau of the Census defines urban places as those with a population of 2,500 or more.

The inventory recorded 13 MSAs within the State of Illinois and 90 non-MSA urban places. Tables 4.1 and 4.2 display the list of MSAs and non-MSA urban places, respectively, used in our analysis. Figure 4.1 shows a map of the 13 MSAs and their largest city.

Secondly, we computed the straight-line distance between each pair of places in the previous two groups using latitude-longitude coordinates from a GIS coverage of the state of Illinois. The place with the largest population marked the coordinate of each MSA.

Table 4.1 MSAs Included in the Analysis

\begin{tabular}{|c|c|}
\hline Metropolitan Statistical Areas in Illinois & Largest City \\
\hline Bloomington & Bloomington \\
\hline Cape Girardeau & Cairo \\
\hline Carbondale-Marion & Carbondale \\
\hline Champaign-Urbana & Champaign \\
\hline Chicago-Naperville-Elgin & Chicago \\
\hline Danville & Danville \\
\hline Davenport-Moline-Rock Island & Moline \\
\hline Decatur & Decatur \\
\hline
\end{tabular}




\begin{tabular}{|c|c|}
\hline Metropolitan Statistical Areas in Illinois & Largest City \\
\hline Kankakee & Kankakee \\
\hline Peoria & Peoria \\
\hline Rockford & Rockford \\
\hline Springfield & Springfield \\
\hline St. Louis & Belleville \\
\hline
\end{tabular}

Table 4.2 Non-MSA Urban Places Included in the Analysis

\begin{tabular}{|l|l|l|l|}
\hline Abingdon & Fairbury & McLeansboro & Robinson \\
\hline Amboy & Fairfield & Mendota & Rochelle \\
\hline Anna & Flora & Metropolis & Rock Falls \\
\hline Arcola & Freeport & Monmouth & Rushville \\
\hline Arthur & Fulton & Morrison & Salem \\
\hline Beardstown & Galena & Mount Carmel & Savanna \\
\hline Benton & Galesburg & Mount Morris & Seneca \\
\hline Bushnell & Hamilton & Mount Vernon & Shelbyville \\
\hline Byron & Harrisburg & Nashville & South Jacksonville \\
\hline Canton & Havana & Newton & Sparta \\
\hline Carmi & Hillsboro & Oglesby & Spring Valley \\
\hline Carthage & Jacksonville & Olney & Sterling \\
\hline Casey & Knoxville & Oregon & Streator \\
\hline Centralia & Lake Holiday & Ottawa & Sullivan \\
\hline Charleston & LaSalle & Pana & Sumner \\
\hline Chester & Lawrenceville & Paris & Taylorville \\
\hline Christopher & Lena & Peru & Tuscola \\
\hline Davis Junction & Lincoln & Pinckneyville & Vandalia \\
\hline Dixon & Litchfield & Pittsfield & Watseka \\
\hline Du Quoin & Macomb & Pontiac & West Frankfort \\
\hline Dwight & Marseilles & Princeton & White Hall \\
\hline Effingham & Marshall & Quincy & \\
\hline Eldorado & Mattoon & Red Bud & \\
\hline & & & \\
\hline
\end{tabular}




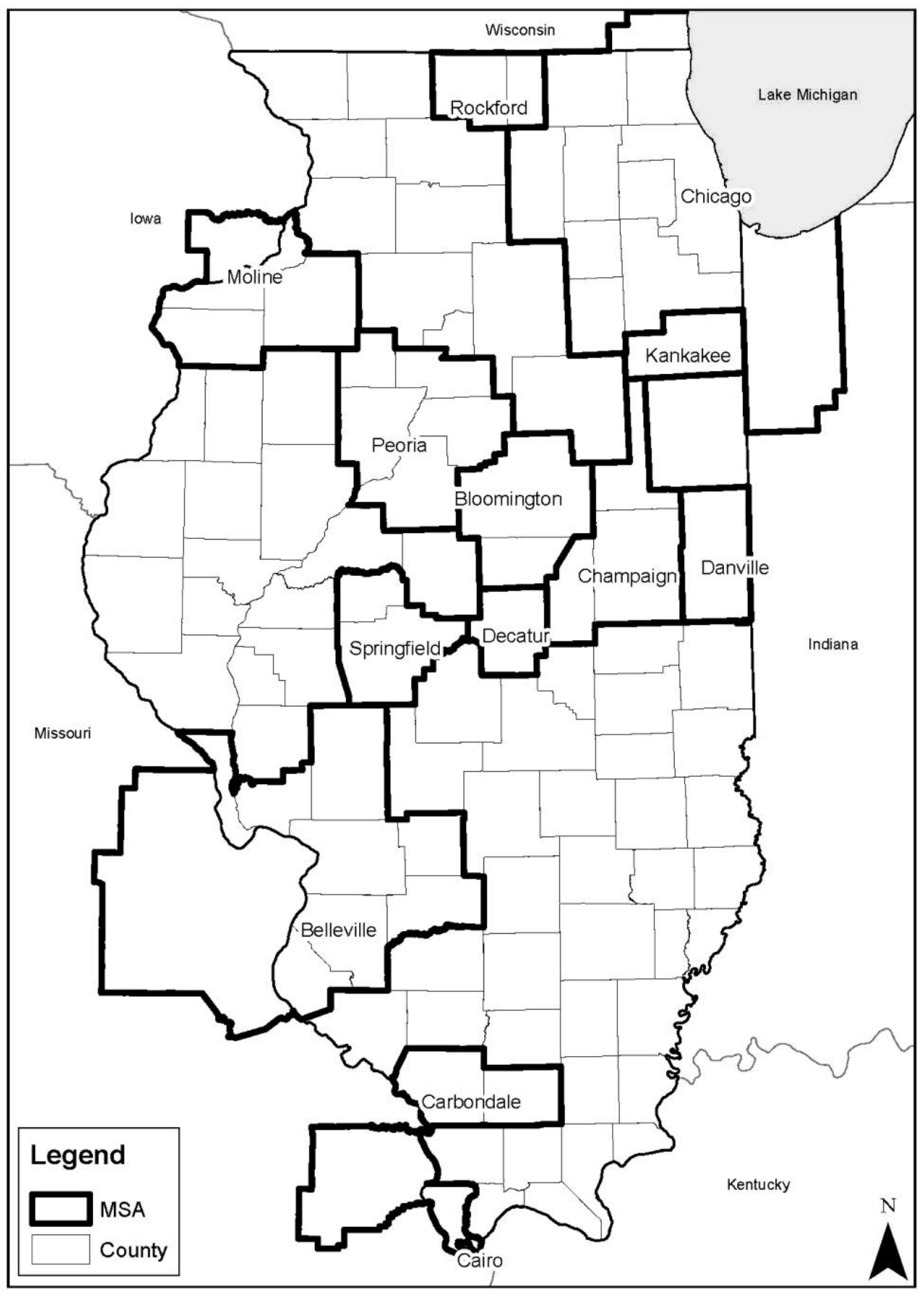

Figure 4.1. Illinois Metropolitan Statistical Areas and Largest Cities. 


\section{Methodology}

The purpose of this part of the project was to rank order city pairs on the basis of estimated demand for intercity bus service. Ideally, the total number of trips between city pairs would be known and an appropriate factor based on historical trends applied to estimate demand. However, such data does not exist for most city pairs in Illinois.

The method that was used is based on the gravity model to develop a scoring function of potential interaction. One formulation of the gravity model is:

$$
\mathrm{T}_{\mathrm{ij}}=\mathrm{G}^{*} \mathrm{Ai}_{\mathrm{i}} \mathrm{A}_{\mathrm{j}} / \mathrm{d}_{2 \mathrm{ij}}
$$

where:

$\mathrm{T}_{\mathrm{ij}}=$ number of trips between place $\mathrm{i}$ and place $\mathrm{j}$

$A_{i}=$ measure of attractiveness of place $i$

$A_{j}=$ measure of attractiveness of place $j$

$\mathrm{dij}_{\mathrm{ij}}$ distance between places $\mathrm{i}$ and $\mathrm{j}$

$\mathrm{G}=\mathrm{a}$ constant of proportionality

A scoring function can then be developed as:

$$
\mathrm{S}_{\mathrm{ij}}=\mathrm{T}_{\mathrm{ij}} / \mathrm{G}_{\mathrm{i}}=\mathrm{Ai}^{*} \mathrm{~A}_{\mathrm{j}} / \mathrm{d}_{2 \mathrm{ij}}
$$

where, $S_{i j}$ is the interactivity potential between place $i$ and place $j$.

If population is used as an attraction, the model says that city pairs $i$ and $j$ would have a higher score and thus greater potential demand for intercity bus service, the larger the populations of the two cities and the closer they are to each other.

The identification of potential markets was accomplished by scoring the interactivity potential between the pairs of places above using the following gravity-type formula:

$$
S_{i j}=\frac{P_{i} \cdot P_{j}}{d^{2}{ }_{i j}}
$$

where,

$P_{i}$ and $P_{j}$ are the (total) populations of the two places $i$ and $j$, respectively

$d_{i j}$ is the distance between the two places,

and $S_{i j}$ is the interactivity potential between place $i$ and place $j$.

The rationale for this approach is that the level of demand for intercity bus service between two places, excluding intermediate stops, would be proportional to the population masses of the 
terminal places and inversely proportional to the squared distance between the places. Note that in traditional demand forecasting, properly estimated population and distance functions would be used.

The method assigns a score to each origin-destination (O-D) pair, sorts the pairs in a descending order by their score, and then ranks all O-D pairs in quartiles, with higher ranked OD pairs corresponding to greater potential for interaction. Both MSAs and non-MSAs were scored. For a better visualization and interpretation of the resulting data, maps were generated. Line coding (varying the width of a connecting line between two places) was used to identify the four quartiles.

The methodology considers MSAs and non-MSA urban places separately. MSAs are large enough so that each may potentially serve as an origin or destination for intercity bus service. Non-MSA urban places, in general however, do not have the population size sufficient to serve as an origin or destination for intercity passenger service. Rather, any intercity service through such areas would be as intermediate points or route deviations on service provided between MSAs.

\section{Demand Scoring Results}

The analysis included the following cases:

1. Internal (Illinois) MSAs to internal MSAs as seen in Figure 4.2.

2. Internal non-MSA urban places to closest MSAs as seen in Figure 4.3.

The analysis for internal to internal MSAs resulted in $13 \times(13-1) / 2=78$ different origin-destination pairs of MSAs, with their respective ranking presented in Figure 4.2. On the map, the MSAs are represented by their largest city. Scores for each O-D pair were then rank ordered and split into four quartile groups. For clarity, Figure 4.2 shows only the highest and lowest scores. OD pairs with the highest scores (represented by thick lines) have the highest potential for interaction. Demand for intercity bus service would be the greatest for city pairs in this quartile ranking. City pairs with the lowest scores have progressively less potential for interaction and thus less potential for intercity bus demand.

Table 4.3 shows the MSA pairs with the highest and lowest scores. Not surprisingly, the Chicago-Naperville-Elgin MSA is involved in the top 10 pairs with highest interactivity potential, either as origin or destination MSA. Of the other MSAs, Bloomington, Champaign-Urbana, St. Louis, Peoria and Springfield scored high as origin or destination MSAs. Conversely, Cape Girardeau appears to have the lowest interactivity potential either as origin or destination MSA. 
Table 4.3 MSA Pairs with Highest and Lowest Interactivity Potential

\begin{tabular}{|c|c|c|c|}
\hline \multicolumn{2}{|c|}{$\begin{array}{l}\text { Highest Interactivity Potential } \\
\text { (in descending order) }\end{array}$} & \multicolumn{2}{|c|}{$\begin{array}{l}\text { Lowest Interactivity Potential } \\
\text { (in ascending order) }\end{array}$} \\
\hline Origin MSA & Destination MSA & Origin MSA & Destination MSA \\
\hline $\begin{array}{l}\text { Chicago-Naperville- } \\
\text { Elgin }\end{array}$ & Rockford & Cape Girardeau & Kankakee \\
\hline $\begin{array}{l}\text { Chicago-Naperville- } \\
\text { Elgin }\end{array}$ & Kankakee & Cape Girardeau & Danville \\
\hline $\begin{array}{l}\text { Chicago-Naperville- } \\
\text { Elgin }\end{array}$ & Peoria & Cape Girardeau & $\begin{array}{l}\text { Davenport-Moline-Rock } \\
\text { Island }\end{array}$ \\
\hline Champaign-Urbana & $\begin{array}{l}\text { Chicago-Naperville- } \\
\text { Elgin }\end{array}$ & Cape Girardeau & Rockford \\
\hline Bloomington & $\begin{array}{l}\text { Chicago-Naperville- } \\
\text { Elgin }\end{array}$ & Cape Girardeau & Decatur \\
\hline St. Louis & $\begin{array}{l}\text { Chicago-Naperville- } \\
\text { Elgin }\end{array}$ & Bloomington & Cape Girardeau \\
\hline $\begin{array}{l}\text { Chicago-Naperville- } \\
\text { Elgin }\end{array}$ & $\begin{array}{l}\text { Davenport-Moline- } \\
\text { Rock Island }\end{array}$ & Cape Girardeau & Champaign-Urbana \\
\hline $\begin{array}{l}\text { Chicago-Naperville- } \\
\text { Elgin }\end{array}$ & Springfield & Cape Girardeau & Peoria \\
\hline $\begin{array}{l}\text { Chicago-Naperville- } \\
\text { Elgin }\end{array}$ & Decatur & Cape Girardeau & Springfield \\
\hline $\begin{array}{l}\text { Chicago-Naperville- } \\
\text { Elgin }\end{array}$ & Danville & Cape Girardeau & Carbondale-Marion \\
\hline Bloomington & Peoria & $\begin{array}{l}\text { Carbondale- } \\
\text { Marion }\end{array}$ & Kankakee \\
\hline Bloomington & Champaign-Urbana & $\begin{array}{l}\text { Carbondale- } \\
\text { Marion }\end{array}$ & Danville \\
\hline Champaign-Urbana & Decatur & St. Louis & Cape Girardeau \\
\hline Decatur & Springfield & $\begin{array}{l}\text { Carbondale- } \\
\text { Marion }\end{array}$ & $\begin{array}{l}\text { Davenport-Moline-Rock } \\
\text { Island }\end{array}$ \\
\hline St. Louis & Springfield & Cape Girardeau & Chicago-Naperville-Elgin \\
\hline Peoria & Springfield & $\begin{array}{l}\text { Carbondale- } \\
\text { Marion }\end{array}$ & Rockford \\
\hline $\begin{array}{l}\text { Davenport-Moline- } \\
\text { Rock Island }\end{array}$ & Peoria & Danville & $\begin{array}{l}\text { Davenport-Moline-Rock } \\
\text { Island }\end{array}$ \\
\hline St. Louis & Carbondale-Marion & $\begin{array}{l}\text { Carbondale- } \\
\text { Marion }\end{array}$ & Decatur \\
\hline Champaign-Urbana & Danville & Bloomington & Carbondale-Marion \\
\hline
\end{tabular}




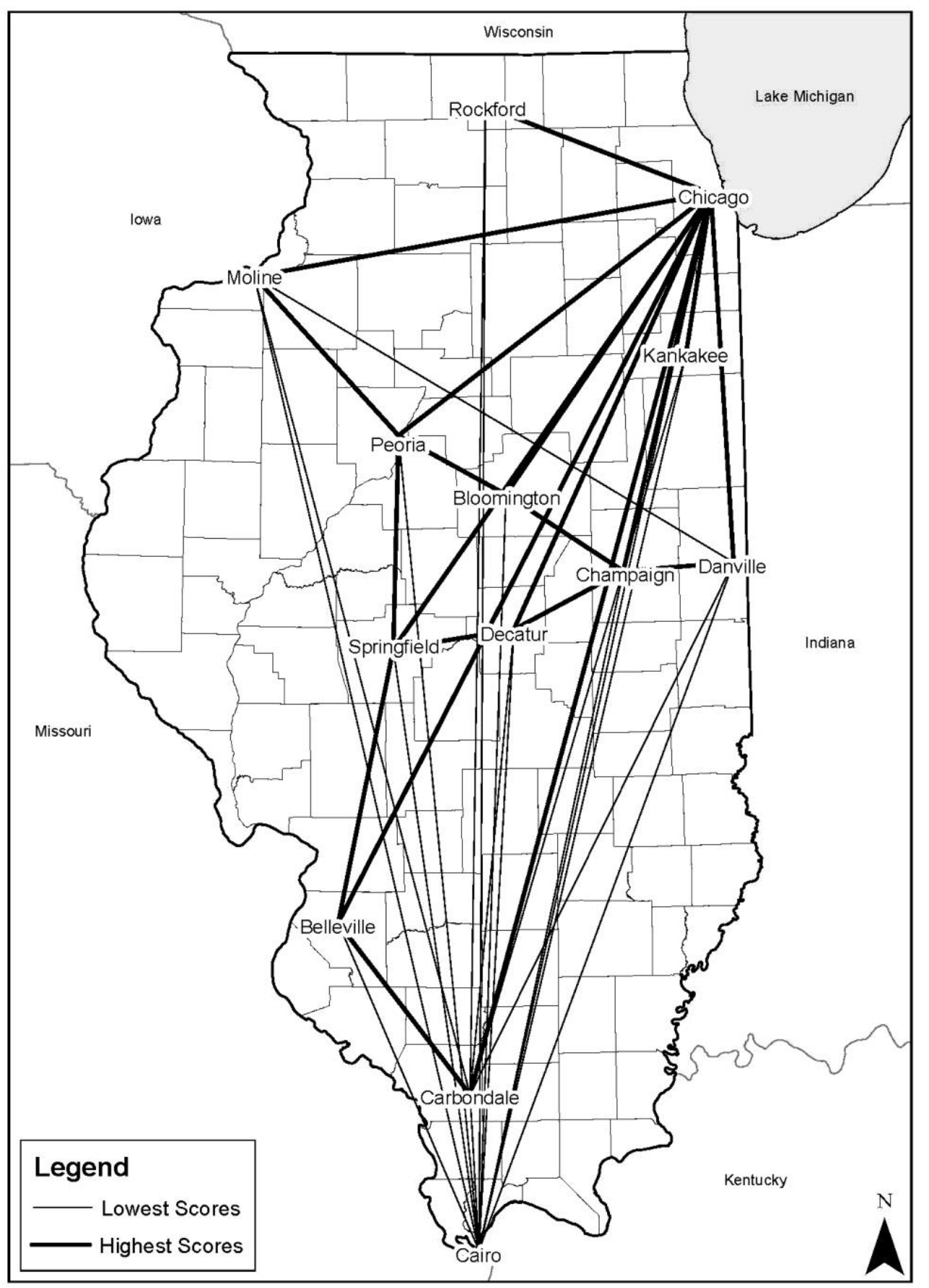

Figure 4.2. Interactivity Potential between MSAs 
The non-MSA urban place analysis followed a slightly different approach. Initially, this analysis calculated the pairwise scores for each non-MSA urban place to all MSAs in the study. In this case, however, almost all O-D pairs with the highest interaction potential (in the first quartile) had as a destination either the St. Louis - Belleville metropolitan area or the Chicago MSA, which are the two largest metropolitan areas in the study area. However, most residents of nonMSA urban places would not travel to Chicago or St. Louis for goods and services available more close at hand. Intervening opportunity theory says that they would travel to the closest city having such goods and services available.

The notion here is that these smaller urban places would have an orientation to an MSA for access to a variety of urban services and activities including intercity bus service. This is based on the concept of central place theory, the idea cities exist in a hierarchy, with smaller cities serving as a market area for larger urban areas. Thus, rather than estimate the potential for interaction of non-MSA urban places to each other, the analysis examined the potential for interaction to the closest MSA.

In view of the above, the following procedure was used in this part of the analysis:

(a) The state of Illinois was divided into market areas defined by one MSA and satellite non-MSA urban areas;

(b) for each market area the pairwise interaction potential between the MSA and the satellite cities was calculated, ranked and grouped into four quartiles;

(c) the results were concatenated so that the first group is composed of the first quartile in each market area, the second group of the second quartile in each market area, etc.

In Figure 4.3, those non-MSA urban places ranked in the first group have the highest potential for interaction with their closest MSA city. Those in the second through fourth groups have progressively lesser potential for interaction. Feeder service to intercity bus service at the closest MSA would have the greatest chance of being financially viable the higher the ranking of the non-MSA urban place. In summary, the scoring results are as follows:

- The St. Louis MSA, for example, has the lowest interaction potential with the cities of Newton, Lawrenceville, Summer and South Jacksonville. The MSA scores highest with the cities of Red Bud, Centralia, Sparta and Mount Vernon.

- The Bloomington MSA scores high with the cities of Lincoln and Pontiac, and low with the city of Fairbury.

- The Cape Girardeau MSA scores low with both Metropolis and Anna.

- The Carbondale-Marion MSA scores low with the cities of Mount Carmel and Fairfield, and high with the cities of West Frankfort and Du Quoin.

- The Champaign-Urbana MSA scores low with the cities of Casey and Arthur, and high with the cities of Charleston and Tuscola.

- The Chicago-Naperville-Elgin MSA scores low with the cities of Amboy, Oregon and Seneca, and high with the cities of Ottawa and Rochelle.

- The Danville MSA scores lows with the city of Robinson and high with the city of Paris. 


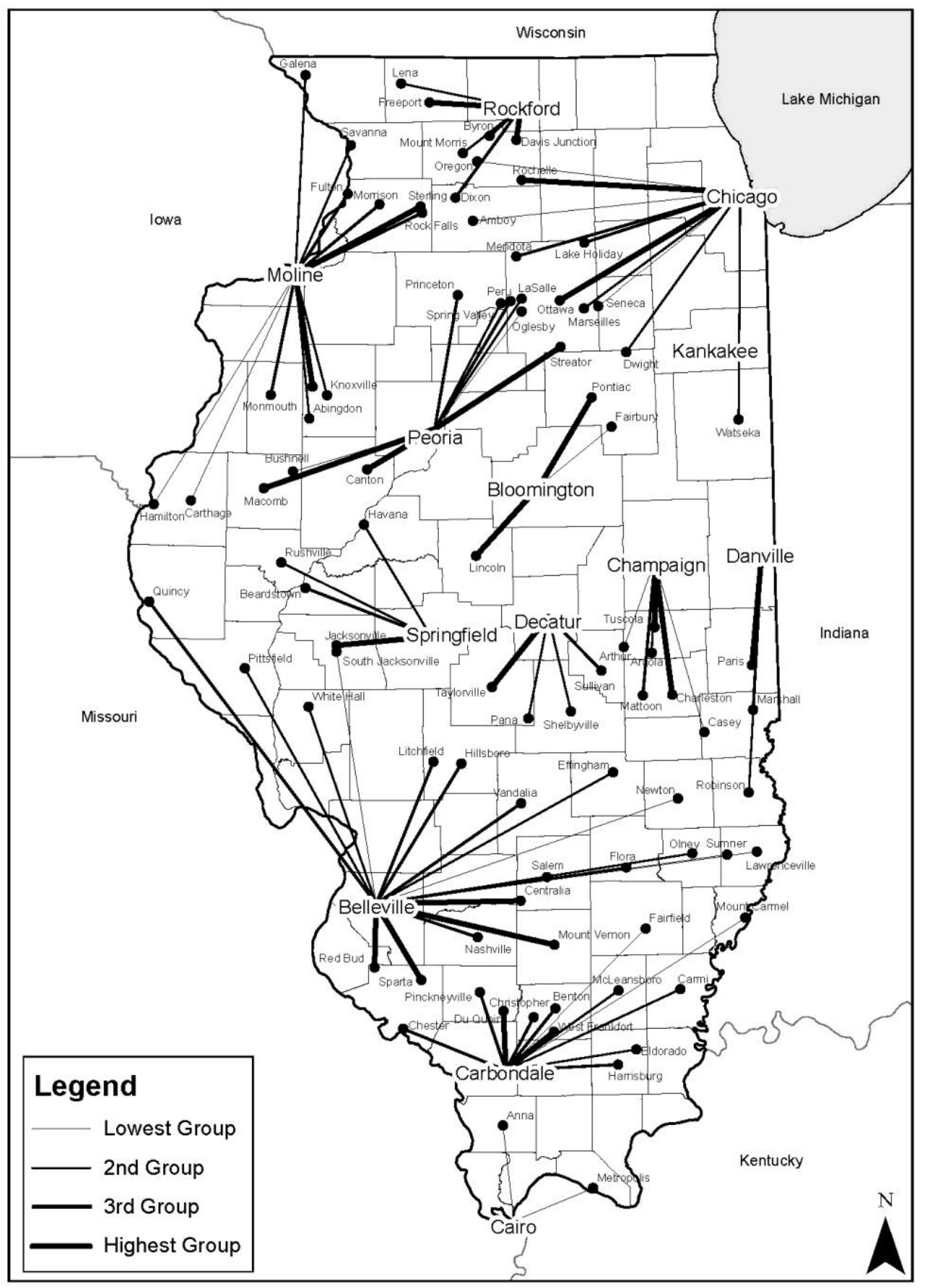

Figure 4.3. Interactivity Potential between non-MSAs and closest MSAs 
- The Decatur MSA scores low with the cities of Shelbyville and Pana, and high the city of Taylorville.

- The Davenport-Moline-Rock Island MSA scores low with the cities of Hamilton and Carthage, and high with the cities of Galesburg and Sterling.

- The Peoria MSA scores low with the cities of Bushnell and Oglesby, and high with the cities of Canton and Streator.

- The Rockford MSA scores low with the cities of Lena and Mount Morris, and high with the cities of Freeport and Davis Junction.

- The Springfield MSA scores low with the cities of Rushville and Havana, and high with the city of Jacksonville.

Table 4.4 shows the complete scoring results. The 90 urban non-MSA places are listed in (ascending) order of interaction potential with their nearest MSA.

Table 4.4 MSA Interactivity Potential between non-MSAs and nearest MSA

\begin{tabular}{|l|l|}
\hline Non-MSA urban place & Nearest MSA \\
\hline Newton & St. Louis \\
\hline Lawrenceville & St. Louis \\
\hline Sumner & St. Louis \\
\hline South Jacksonville & St. Louis \\
\hline White Hall & St. Louis \\
\hline Pittsfield & St. Louis \\
\hline Flora & St. Louis \\
\hline Olney & St. Louis \\
\hline Effingham & St. Louis \\
\hline Vandalia & St. Louis \\
\hline Salem & St. Louis \\
\hline Quincy & St. Louis \\
\hline Litchfield & St. Louis \\
\hline Nashville & St. Louis \\
\hline Hillsboro & St. Louis \\
\hline Mount Vernon & St. Louis \\
\hline Sparta & St. Louis \\
\hline Centralia & St. Louis \\
\hline
\end{tabular}




\begin{tabular}{|l|l|}
\hline Non-MSA urban place & Nearest MSA \\
\hline Red Bud & St. Louis \\
\hline Fairbury & Bloomington \\
\hline Pontiac & Bloomington \\
\hline Lincoln & Bloomington \\
\hline Anna & Cape Girardeau \\
\hline Metropolis & Cape Girardeau \\
\hline Mount Carmel & Carbondale-Marion \\
\hline Fairfield & Carbondale-Marion \\
\hline Carmi & Carbondale-Marion \\
\hline McLeansboro & Carbondale-Marion \\
\hline Eldorado & Carbondale-Marion \\
\hline Chester & Carbondale-Marion \\
\hline Harrisburg & Carbondale-Marion \\
\hline Christopher & Carbondale-Marion \\
\hline Pinckneyville & Carbondale-Marion \\
\hline Benton & Carbondale-Marion \\
\hline Du Quoin & Carbondale-Marion \\
\hline West Frankfort & Carbondale-Marion \\
\hline Casey & Champaign-Urbana \\
\hline Arthur & Champaign-Urbana \\
\hline Arcola & Champaign-Urbana \\
\hline Mattoon & Champaign-Urbana \\
\hline Tuscola & Champaign-Urbana \\
\hline Charleston & Champaign-Urbana \\
\hline Amboy & Chicago-Naperville-Elgin \\
\hline Oregon & Chicago-Naperville-Elgin \\
\hline Seneca & Chicago-Naperville-Elgin \\
\hline Watseka & \\
\hline
\end{tabular}




\begin{tabular}{|l|l|}
\hline Non-MSA urban place & Nearest MSA \\
\hline Dwight & Chicago-Naperville-Elgin \\
\hline Marseilles & Chicago-Naperville-Elgin \\
\hline Mendota & Chicago-Naperville-Elgin \\
\hline Lake Holiday & Chicago-Naperville-Elgin \\
\hline Rochelle & Chicago-Naperville-Elgin \\
\hline Ottawa & Chicago-Naperville-Elgin \\
\hline Robinson & Danville \\
\hline Marshall & Danville \\
\hline Paris & Danville \\
\hline Shelbyville & Decatur \\
\hline Pana & Decatur \\
\hline Sullivan & Decatur \\
\hline Taylorville & Decatur \\
\hline Hamilton & Davenport-Moline-Rock Island \\
\hline Carthage & Davenport-Moline-Rock Island \\
\hline Galena & Davenport-Moline-Rock Island \\
\hline Abingdon & Davenport-Moline-Rock Island \\
\hline Savanna & Davenport-Moline-Rock Island \\
\hline Knoxville & Davenport-Moline-Rock Island \\
\hline Morrison & Davenport-Moline-Rock Island \\
\hline Fulton & Davenport-Moline-Rock Island \\
\hline Rock Falls & Davenport-Moline-Rock Island \\
\hline Monmouth & Davenport-Moline-Rock Island \\
\hline Sterling & Davenport-Moline-Rock Island \\
\hline Galesburg & Davenport-Moline-Rock Island \\
\hline Bushnell & Peoria \\
\hline Oglesby & Peoria \\
\hline Spring Valley & \\
\hline
\end{tabular}




\begin{tabular}{|l|l|}
\hline Non-MSA urban place & Nearest MSA \\
\hline LaSalle & Peoria \\
\hline Princeton & Peoria \\
\hline Peru & Peoria \\
\hline Macomb & Peoria \\
\hline Streator & Peoria \\
\hline Canton & Peoria \\
\hline Lena & Rockford \\
\hline Mount Morris & Rockford \\
\hline Dixon & Rockford \\
\hline Byron & Rockford \\
\hline Davis Junction & Rockford \\
\hline Freeport & Rockford \\
\hline Rushville & Springfield \\
\hline Havana & Springfield \\
\hline Beardstown & Springfield \\
\hline Jacksonville & Springfield \\
\hline
\end{tabular}




\section{CHAPTER 5}

\section{CONCLUSIONS}

As intercity bus services have reemerged as a viable modal alternative between metropolitan areas this report examines the market potential in Illinois. In this regard, we have reviewed the regulatory environment, before and after deregulation, summarized federal requirements, as well as relevant policies and regulations from the Illinois Commerce Commission, and the Illinois Department of Transportation.

A survey of state intercity bus programs revealed that states continue to implement programs to support intercity bus services, but challenges for rural areas remain. More specifically,

- coordination among states for intercity bus services across state lines is not common;

- states continue to use Section 5311(f) funding to subsidize operations;

- $\quad$ private for-profit carriers most often apply and receive 5311(f) funding; and

- coordination between intercity bus services and Amtrak is lacking

The market analysis revealed a number of metropolitan areas with high interaction potential. Moreover, the analysis found that several urban places outside of metropolitan areas exhibit high interaction potential with their nearest metropolitan area implying that they could serve as additional intermediate stops of intercity bus services between metropolitan areas.

Additional research in the future could strengthen the demand analysis in this study to include, for example, urban places and metropolitan areas in neighboring states. Moreover, in order to assess whether intercity bus needs are being met in the State of Illinois, an analysis of existing intercity bus services in Illinois would need to be carried out. 


\section{REFERENCES}

Ashiabor, S., H. Baik, and A. Trani (2007). Logit Models for Forecasting Nationwide Intercity Travel Demand in the United States. Transportation Research Record: Journal of the Transportation Research Board, 2007, pp. 1-12.

Augustina, K., R. Gerikeb, M.J. Martinez Sanchez, and C. Ayala (2014). Analysis of Intercity Bus Markets on Long Distances in an Established and a Young Market: The Example of the U.S. and Germany. Research in Transportation Economics 48, pp. 245-254.

Burch, J.S. (1961). Traffic Interactance between Cities. HRB Bulletin 297, HRB, National Research Council, Washington, D.C., pp. 14-17.

Fravel, F. and R. Barboza. (2012) Development and Application of a Rural Intercity Demand Model. Journal of Public Transportation, 15(3), pp. 25-39.

Fravel, F.D., R. Barboza, J. Quan, and J.K. Sartori (2011). Toolkit for Estimating Demand for Rural Intercity Bus Services. TCRP Report 147. Transportation Research Board, Washington, D.C.

Gibert, G. (1974). Recreational Travel Behavior: The Case for Disaggregate, Probabilistic Models. In Special Report 149, TRB, National Research Council, Washington, D.C., pp. 223230.

Horowitz, A. (2006). Statewide Travel Forecasting Models: A Synthesis of Highway Practice. NCHRP Synthesis 358. National Cooperative Highway Research Program. Transportation Research Board, National Research Council, Washington, D.C.

Hough, J. and J. Mattson (2016). The Changing State of Rural Transit: Challenges, Trends, Benefits, and Innovations. In TR News, Number 303, May-June 2016, pp. 34-37.

Transportation Research Board, Washington, D.C.

Kahn, A.E. (1990). Deregulation: Looking Backward and Looking Forward. Yale Journal on Regulation, 7(2), pp. 325-354.

Klein, N.J. (2015). Get on (Curbside) Bus: The New Intercity Bus. The Journal of Transport and Land Use 8(5), pp. 155-169. World Society for Transport and Land Use (WSTLUR), published University of Minnesota Center for Transportation Studies.

Klein, N.J. (2009). Emergent Curbside Intercity Bus Industry: Chinatown and Beyond.

Transportation Research Record: Journal of the Transportation Research Board, No. 2111, Transportation Research Board of the National Academies, Washington, D.C., 2009, pp. 83-89. 
Koppelman, F.S., G-K. Kuah, and M. Hirsch (1984). Review of Intercity Passenger Demand Modeling: Mid-60's to the Mid-80s. The Transportation Center, Northwestern University, Evanston, Illinois.

Mallett, W.J. (2001). Long-distance Travel by Low-income Households. Transportation Research Circular, Number E-C026, March 2001. Transportation Research Board, National Research Council. Washington, D.C., 169-177.

Moavenzadeh, F., M.J. Markow, B.D. Brademeyer, and K.N.A. Safwat (1983). A Methodology for Intercity Transportation Planning in Egypt. Transportation Research - A, Vol. 17A, No. 6, pp. 481-491.

Stephen D Nutley, S.D. (1996). Rural Transport Problems and Non-car Populations in the USA: A UK Perspective. Journal of Transport Geography 4(2), pp 93-106.

Oberhausen, P.J. and F.S. Koppelman (1982). Time-Series Analysis of Intercity Air Travel Volume. Transportation Research Record 840, TRB, National Research Council, Washington, D.C., pp. 15-21.

Oster Jr., C.V. and C.K. Zorn (1986). Impacts of Regulatory Reform on Intercity Bus Service in the United States. Transportation Journal, 25(3), pp. 33-42.

O'Toole, R. (2011). Intercity Buses: The Forgotten Mode. Policy Analysis, No 680. Cato Institute, Washington, D.C.

Pagano, A., P. Metaxatos, E. Holeman, V. Mora, A. Morreale and K. Stanis (2001). Development of Intercity Bus Strategic Plan and Program. Final Report. Illinois Department of Transportation. November 2001.

Phillips, K.B. (1990). Intercity Bus Deregulation: Origins and Consequences. Transportation Practitioners Journal, 57(4). Washington, D.C.

Resource Systems Group (2015). Developing Refined Estimates of Intercity Bus Ridership. Final Report. FHWA Report DTFH6114P00097. Federal Highway Administration, Washington, D.C.

Schwieterman, J.P. (2016). The Decline and Revival of Intercity Bus Service. In TR News, Number 303, May-June 2016, pp. 4-10. Transportation Research Board, Washington, D.C.

Schweiterman, J.P. and L. Ames Fischer (2012). Competition from the Curb: Survey of Passengers on Discount Curbside Bus Operators in Eastern and Midwestern U.S. Cities. Chaddick Institute of Metropolitan Development, School of Public Service, DePaul University. 
Scott, M., E. Collins, and A. Wicks, III (2013). Curbside Intercity Bus Industry: Research of Transportation Policy Opportunities and Challenges. University of Delaware, August 2013.

Sperling, D. and R. Goralka (1988). Transportation Research Record 1202, TRB, National Research Council, Washington, D.C., pp. 106-112.

Stommes, E.S. and D.M. Brown (2002). Transportation in Rural America: Issues for the $21 \mathrm{st}$ Century, Community Transportation 16(4). Community Transportation Association, Washington, D.C.

U.S. Department of Transportation, Federal Highway Administration (1973). Statewide Travel Demand Forecasting. Washington, D.C.

U.S. Department of Transportation, Federal Highway Administration (1999). Guidebook on Statewide Travel Forecasting. March 1999, Washington, D.C.

Yang, H. and C.R. Cherry (2012). Statewide Rural-Urban Bus Travel Demand and Network Evaluation: An Application in Tennessee. Journal of Public Transportation, 15(3), pp 97-111. 


\section{APPENDIX 1}

\section{SURVEY QUESTIONS}

1. Which state dot do you represent?

2. What is your title at your organization?

3. How many private carriers offer services in your state?

4. Has the number of private rural intercity carriers/providers:
A. Increased over the last five years
B. Remained unchanged over the last five years
C. Decreased over the last five years
D. Do not know

5. For private carriers, rural intercity bus (section 5311 (f)) funding has:
A. Increased over the last five years
B. Remained unchanged over the last five years
C. Decreased over the last five years
D. Did not provide funding to private carriers
E. Do not know

6. For private carriers, rural intercity routes in my state have:
A. Been abandoned over the last five years (please specify how many routes)
B. Remained unchanged over the last five years
C. Been added over the last five years (please specify how many routes)
D. Do not know

7. The number of rural intercity scheduled stops has:
A. Increased over the last five years
B. Remained unchanged over the last five years
C. Decreased over the last five years
D. Do not know

8. On average, how many routes do the private carriers operate each week?

9. Do your state's supported intercity bus carriers provide service across state lines?
A. If yes, is your state's support coordinated with a neighboring state?
B. If yes, which states and routes?

10. In terms of total intercity bus route mileage, what percentage of privately provided intercity bus routes are unsubsidized versus subsidized? (for example, your state has two intercity bus routes. One is 50 miles and is subsidized with $5311(\mathrm{f})$ funds. The other is 75 miles and is not subsidized. Therefore, your state subsidizes $40 \%$ of total route miles).

11. In your most recently completed fiscal year, did you submit a certification or partial certification to the FTA that existing services adequately met your state's intercity bus needs?

A. If yes, did you complete a needs analysis?

B. If yes, are your state's intercity bus needs currently being met?

12. To make a reasonable case that needs are being met, did your state (check all the apply):
A. Conduct own in-house research
B. Contract with an outside vendor 
C. Contract with a university for research

D. Other

13. Overall, does your intercity bus program emphasize (choose one)
A. Operating subsidies
B. Capital projects
C. Marketing and support projects
D. Other

14. Which entities have most often applied for and/or received 5311(f) funds (choose one)
A. Private, for-profit intercity carriers
B. Private, non-profit intercity carriers
C. Local transit providers
D. Other public entities

15. Please explain your evaluation process and criteria for 5311 (f) applications.

16. To whom does your state disburse 5311(f) funds? (check all that apply)
A. County governments
B. Public rural transit providers
C. Other government agencies
D. Private providers

17. Has your state experienced problems in spending the $15 \%$ requirement for rural intercity bus?

18. Has your state contributed 5311 (f) funding to build transfer facilities for intercity bus carriers?

19. Could your state more fully spend its $15 \%$ apportionment for 5311 (f) funding if destinations could be not only intercity bus transfer points but also rail, ferry, and airport destinations?

20. Does your state have combined ticketing with an intercity bus and Amtrak option?

21. Is there Amtrak branded intercity bus service in your state to connect to rail?

22. Does your state provide outreach or education to service providers about 5311(f) funding?

23. May we contact you if we have additional questions? If yes, please specify your email below. 